\title{
Characteristics, sources, and reactions of nitrous acid during winter at an urban site in the Central Plains Economic Region in China
}

\author{
Qi Hao ${ }^{1}$, Nan Jiang ${ }^{2}$, Ruiqin Zhang ${ }^{2}$, Liuming Yang ${ }^{1}$, and Shengli $\mathbf{L i}^{2}$ \\ ${ }^{1}$ College of Chemistry, Zhengzhou University, Zhengzhou 450001, China \\ ${ }^{2}$ School of Ecology and Environment, Zhengzhou University, Zhengzhou 450001, China
}

Correspondence: Nan Jiang (jiangn@ zzu.edu.cn)

Received: 9 October 2019 - Discussion started: 29 October 2019

Revised: 29 January 2020 - Accepted: 14 May 2020 - Published: 16 June 2020

\begin{abstract}
Nitrous acid (HONO) in the core city of the Central Plains Economic Region in China was measured using an ambient ion monitor from 9 to 31 January 2019. Measurement time intervals were classified into the following periods in accordance with the daily mean values of $\mathrm{PM}_{2.5}$ : clean days (CDs), polluted days (PDs), and severely polluted days (SPDs). The HONO concentrations during CD, PD, and SPD periods were 1.2, 2.3, and $3.7 \mathrm{ppbv}$, respectively. The contributions of the homogeneous reaction, heterogeneous conversion, and direct emissions to HONO sources varied under different pollution levels. The mean values of the net HONO production of the homogeneous reaction $\left(P_{\mathrm{OH}+\mathrm{NO}}^{\text {net }}\right)$ in $\mathrm{CD}$, $\mathrm{PD}$, and SPD periods were $0.13,0.26$, and $0.56 \mathrm{ppbv}^{-1}$, respectively. The average conversions of $\mathrm{NO}_{2}\left(C_{\mathrm{HONO}}\right)$ in $\mathrm{CD}, \mathrm{PD}$, and SPD periods were $0.72 \times 10^{-2}, 0.64 \times 10^{-2}$, and $1.54 \times 10^{-2} \mathrm{~h}^{-1}$, respectively, indicating that the heterogeneous conversion of $\mathrm{NO}_{2}$ was less important than the homogeneous reaction. Furthermore, the net production of the homogeneous reaction may have been the main factor in the increase of HONO under high- $\mathrm{NO}_{x}$ conditions (i.e., when the concentration of $\mathrm{NO}$ was higher than that of $\mathrm{NO}_{2}$ ) at nighttime. Daytime HONO budget analysis showed that the mean values of the unknown source $\left(P_{\text {unknown }}\right)$ during $\mathrm{CD}$, $\mathrm{PD}$, and SPD periods were $0.26,0.40$, and $1.83 \mathrm{ppbv} \mathrm{h}^{-1}$, respectively. The values of $P_{\mathrm{OH}+\mathrm{NO}}^{\text {net }}, C_{\mathrm{HONO}}$, and $P_{\text {unknown }}$ in the SPDs period were comparatively larger than those in other periods, indicating that HONO participated in many reactions. The proportions of nighttime HONO sources also changed during the entire sampling period. Direct emissions and a heterogeneous reaction controlled HONO production in the first half of the night and provided a contribution that is larger than that of the homogeneous reaction. The pro-
\end{abstract}

portion of homogenization gradually increased in the second half of the night due to the steady increase in NO concentrations. The hourly level of HONO abatement pathways, except for $\mathrm{OH}+\mathrm{HONO}$, was at least $0.22 \mathrm{ppbvh}^{-1}$ in the SPDs period. The cumulative frequency distribution of the $\mathrm{HONO}_{\text {emission}} / \mathrm{HONO}$ ratio (less than $20 \%$ ) was approximately $77 \%$, which suggested that direct emission was not important. The heterogeneous HONO production increased when the relative humidity (RH) increased, but it decreased when RH increased further. The average $\mathrm{HONO} / \mathrm{NO}_{x}$ ratio $(4.9 \%)$ was more than twice the assumed globally averaged value $(2.0 \%)$.

\section{Introduction}

Nitrous acid (HONO) is important in the photochemical cycle and can provide hydroxyl radicals $(\cdot \mathrm{OH}$; Harrison et al., 1996) as follows:

$\mathrm{HONO}+h v \rightarrow \cdot \mathrm{OH}+\mathrm{NO}(300 \mathrm{~nm}<\lambda<405 \mathrm{~nm})$.

According to measurement and simulation studies (Alicke et al., 2002), the contribution of $\mathrm{HONO}$ to $\cdot \mathrm{OH}$ concentrations can reach $25 \%-50 \%$, especially when the concentration of $\mathrm{OH}$ radicals produced by the photolysis of ozone, acetone, and formaldehyde is relatively low ( $2-3 \mathrm{~h}$ after sunrise; Czader et al., 2012). HONO photolysis was the most important primary source of $\cdot \mathrm{OH}$ that contributed up to $46 \%$ of the total primary production rate of radicals for daytime conditions (Tan et al., 2018). $\cdot O H$ is an important oxidant in the atmosphere, and it can react with organic substances, control the oxidation capacity of the atmosphere, and accelerate 
the formation of secondary aerosols in the urban atmosphere (Sörgel et al., 2011). Therefore, the changes in the contribution of the homogeneous reaction, heterogeneous conversion, and direct emissions during pollution can be observed by studying the formation mechanism of HONO.

Several instruments have been used to determine ambient HONO concentrations, and these include the following: a differential optical absorption spectrophotometer (DOAS; Elshorbany et al., 2012; Winer and Biermann, 1994); a long path absorption photometer (LOPAP; Heland et al., 2001); a wet chemical derivatization technique (HPLC) coupled with UV-VIS detection (collectively HPLC/UV-VIS; Michoud et al., 2014); a stripping coil-UV/VIS absorption photometer (SC-AP; Pinto et al., 2014); an incoherent broadband cavityenhanced absorption spectroscope (IBBCEAS; Duan et al., 2018); a chemical ionization mass spectrometer (CIMS; Hirokawa et al., 2009; Roberts et al., 2010); and an ambient ion monitor (AIM; VandenBoer et al., 2014). A result comparison of the different instruments showed that the SC-AP is compatible with two spectral measurement instruments, namely LOPAP and DOAS (Pinto et al., 2014). Compared to HONO measured by the SC-AP deployed on site, HONO measured by AIM has a small error and is within the acceptable analytical uncertainty (VandenBoer et al., 2014). Previous studies have reported that HONO concentrations range from a few parts per trillion by volume (pptv) in clean, remote areas to several parts per billion by volume (ppbv; 0.1$2.1 \mathrm{ppbv}$ ) in air-polluted urban areas (Hou et al., 2016; Michoud et al., 2014).

The sources of HONO are direct emissions and homogeneous and heterogeneous reactions (Acker et al., 2005; Grassian, 2001; Kurtenbach et al., 2001). HONO can be directly discharged into the atmosphere during vehicle operations and biomass combustion. Through a tunneling experiment, Kurtenbach et al. (2001) discovered that motor vehicles emit a small amount of $\mathrm{HONO}$, and the $\mathrm{HONO} / \mathrm{NO}_{x}$ ratio of HONO combustion sources (aside from $\mathrm{NO}_{x}$ and other pollutants) is $0.1 \%-0.8 \%$. Another study showed that the homogeneous reaction of $\mathrm{NO}$ and $\mathrm{OH}$ radicals is a major source of HONO under increased NO concentrations (Spataro et al., 2013). Furthermore, HONO can react with the $\cdot \mathrm{OH}$ (Alicke et al., 2003; Vogel et al., 2003). Tong et al. (2015) used $\mathrm{NO}+\mathrm{OH}$ and $\mathrm{HONO}+\mathrm{OH}$ homogeneous reactions to calculate the net generation rate of HONO homogeneous reactions at night, which are expressed as follows:

$\mathrm{NO}+\cdot \mathrm{OH} \rightarrow \mathrm{HONO}$

$\mathrm{HONO}+\cdot \cdot \mathrm{OH} \rightarrow \mathrm{NO}_{2}+\mathrm{H}_{2} \mathrm{O}$.

Such calculations have been applied in studies on homogeneous reactions and daytime budgets (Hou et al., 2016; Huang et al., 2017). These are studies of homogeneous reactions, and some researchers have begun to explore the mechanism of $\mathrm{NO}_{2}$ heterogeneous reactions. Finlayson-Pitts et al. (2003) studied the mechanism of chemical adsorption of
$\mathrm{NO}_{2}$, and $\mathrm{H}$ ions were revealed on the adsorbed surface by using isotope-labeled water as follows:

$2 \mathrm{NO}_{2}+\mathrm{H}_{2} \mathrm{O} \rightarrow \mathrm{HONO}+\mathrm{HNO}_{3}$.

In China, most studies of HONO have been focused on the Yangtze River Delta, Pearl River Delta, and Jing-Jin-Ji region. For example, Hao et al. (2006) reported that field measurement results, especially $\mathrm{HONO} / \mathrm{NO}_{2}$ and relative humidity $(\mathrm{RH})$, have a significant correlation and proved that heterogeneous reactions are an important source of nighttime HONO. Although the specific chemical mechanisms of heterogeneous reactions remain unknown, the intensity of $\mathrm{HONO}$ formation by $\mathrm{NO}_{2}$ can be expressed by the $\mathrm{HONO}$ conversion frequency (Alicke et al., 2002; Li et al., 2012). $\mathrm{Su}$ et al. (2008a) revealed the importance of the $\cdot \mathrm{OH}$ from HONO during daytime (09:00-15:00 local time or LT) and found that many unknown sources that are closely related to the solar radiation lead to HONO formation. The unknown sources of $\mathrm{HONO}$ may include the $\mathrm{NO}_{2}$ photolysis of sooty surfaces and adsorbed nitric acid and nitrate at UV wavelengths (Kleffmann et al., 1999). The homogeneous nucleation of $\mathrm{NO}_{2}, \mathrm{H}_{2} \mathrm{O}$, and $\mathrm{NH}_{3}$ is the HONO-formation pathway (Zhang and Tao, 2010). Meanwhile, HONO can deposit and react with amines to form nitrosamines (Li et al., 2012) for sinking. The method of budget analysis needs to include the HONO sources and sinks. Researchers suggested that the method of budget analysis is crucial for obtaining the missing source. Spataro et al. (2013) measured the HONO level in Beijing's urban area and discussed the spatiotemporal changes, meteorological effects, and contributions of HONO from different sources. They used the measured HONO data to compare pollution periods in Beijing's urban and suburban areas. Tong et al. (2015) discovered that the pathway of the HONO-formation mechanism, namely direct emissions, heterogeneous formation, and homogeneous reaction, is the same, but the pathway is different at the two sites. A few studies (Cui et al., 2018; Hou et al., 2016) compared the characteristics and sources of HONO during severe pollution periods and clean periods. Although the definitions of the two periods are different, both can be used to analyze the diurnal variation, source, and daytime budget of HONO during the aggravation of pollution.

There is no study of HONO in the Central Plains Economic Region (CPER) in China, with a total population of 0.18 billion at the end of 2011. CPER is an important region for food production and modern agriculture, as published by the Chinese government (http://www.gov.cn/ zhengce/content/2011-10/07/content_8208.htm, last access: 10 September 2019). The document described the different factors that affect atmospheric pollution, including the level of economic development, energy structure, industrial structure, and geographical location (solar radiation) in the Yangtze River Delta, Pearl River Delta, and Jing-Jin-Ji region. As the core city of CPER, Zhengzhou is characterized by severe PM (particulate matter) pollution (Jiang et 
al., 2017, 2018d) and is thus selected for this study. In recent years, comprehensive PM research has been conducted on the chemical characteristics of PM in Zhengzhou (Jiang et al., 2018b; Li et al., 2019) regarding source apportionment (Jiang et al., 2018c, e; Liu et al., 2019), health risks (Jiang et al., 2019a, b), and emission-source profiles (Dong et al., 2019; Jiang et al., 2018a). However, no study has been performed on the sources and characteristics of HONO in Zhengzhou. Moreover, no synthetic research on different pollution levels in the area is available. In the current study, AIM was used to sample and analyze HONO concentrations. The interactions between $\mathrm{HONO}$ and other factors, such as $\mathrm{PM}_{2.5}$ during pollution, were assessed to understand the formation, influence, and removal of HONO on different pollution periods. The levels of $\mathrm{PM}_{2.5}$ were divided into three periods to analyze the HONO sources, sinks, and reactions in different periods. Many papers (Huang et al., 2017; Tong et al., 2016) took $\mathrm{PM}_{2.5}$ as the main control factor of HONO and studied the differences between HONO sources and characteristics during clean and polluted periods. No homogeneous reaction, direct emission, heterogeneous reaction, or daytime budget analysis was conducted during the period of worsening pollution (named the HD period in this paper). Total $\mathrm{NO}_{x}$ emissions in cities with different leading factors of emissions have been declining year by year due to the Chinese government's emission control measures, but some Chinese cities are still in high- $\mathrm{NO}_{x}$ areas (e.g., Beijing, Shanghai, Guangzhou, and Zhengzhou; Kim et al., 2015; Liu et al., 2017). Under high- $\mathrm{NO}_{x}$ conditions, some papers (Cui et al., 2018; Hou et al., 2016) suggested that the heterogeneous reaction was the main source of $\mathrm{HONO}$ and did not conduct a quantitative analysis of homogeneous reaction especially in winter. So, we explore relevant studies of homogeneous reactions. In addition, the source contributions of HONO that varied with the degree of pollution at night were not explained. RH was also analyzed to provide a detailed understanding of HONO-generation intensity under different RH conditions. Analysis of the sources of HONO at night provides strong support for conducting HONO budget analysis during the daytime. To the best of the authors' knowledge, the formation characteristics of HONO at continuous and high time resolutions and different pollution levels have not been studied in Zhengzhou. This work can assist the governments of the CPER in formulating a policy to decrease the level of $\mathrm{HONO}$ precursors, i.e., $\mathrm{NO}$ and $\mathrm{NO}_{2}$, and direct HONO emissions from vehicles.

\section{Experiment and methods}

\subsection{Sampling site and period}

The sampling site is on the rooftop (sixth floor) of a building at Zhengzhou University $\left(34^{\circ} 48^{\prime} \mathrm{N}, 113^{\circ} 31^{\prime} \mathrm{E}\right)$, which is located in the northwestern part of Zhengzhou, China. The observation height is about $20 \mathrm{~m}$ from the ground, and the observation platform is relatively open and without any tall buildings around. The site is about $500 \mathrm{~m}$ from the West Fourth Ring Road of Zhengzhou and about $2 \mathrm{~km}$ from the Lian Huo Expressway to the north. The measurement period was from 9 to 31 January 2019. Daily data were divided into two periods, namely daytime (07:00-18:00 LT) and nighttime (19:00-06:00 LT, i.e., the morning of the next day).

\subsection{Instruments}

AIM (URG-9000D, Thermo Fisher Scientific, USA), an online ion chromatographic monitoring system for particle and gas components in the atmosphere, was used to measure HONO concentration continuously at a temporal resolution of $1 \mathrm{~h}$. The atmospheric airflow entered the $\mathrm{PM}_{2.5}$ cyclone cutting head through the sample tube, and gas-solid separation was performed with a parallel plate denuder with a new synthetic polyamide membrane. The denuder had no moving parts and could be changed without stopping the sampler. HONO was absorbed by the denuder with an absorption liquid ( $5.5 \mathrm{~mol} \mathrm{~m}^{-3} \mathrm{H}_{2} \mathrm{O}_{2}$ ). The chemicals that could be oxidized were absorbed by $\mathrm{H}_{2} \mathrm{O}_{2}$ on the porous membrane surface, but several gases (e.g., $\mathrm{O}_{2}$ and $\mathrm{N}_{2}$ ) were expelled by the air pump. The abundance of other gaseous acids and bases affected the efficiency of HONO collection by AIM due to the relationship between Henry's law constant and $\mathrm{pH}$. This measurement method and its details have been successfully evaluated in many field studies (Markovic et al., 2012; Wang et al., 2019; Yang et al., 2020), as shown in the Supplement. In addition, a QXZ1.0 automatic weather station (Yigu Technologies, China) was used for the synchronous observation of meteorological parameters, including temperature $(T), \mathrm{RH}$, wind direction (WD), and wind speed (WS). The temporal resolution of the model analysis system that integrates these types of observation instruments (TE - used for measuring $\mathrm{O}_{3} ; 48 \mathrm{i}$ - used for measuring $\mathrm{CO} ; 42 \mathrm{i}$ - used for measuring $\mathrm{NO}, \mathrm{NO}_{x}$, and $\mathrm{NO}_{2}$ ]; and TEOM $1405 \mathrm{PM}_{2.5}$ monitor used for measuring $\mathrm{PM}_{2.5}$; Thermo Fisher Scientific, USA) is $1 \mathrm{~h}$. Detailed information can be found in the work of Wang et al. (2019). Measurement technique, detection limit, and accuracy of measured species are shown in Table S1 in the Supplement.

During the sampling period, all instruments were subjected to strict quality controls to avoid possible contamination. The instrument accessories and sampling process were periodically replaced and calibrated, respectively. The instrument parts and consumables were changed before the observation process, and the sampling flow was calibrated to reduce the negative effect of the accessories. Before this measurement period, the membrane of the denuder was replaced and standard anion and cation solutions were prepared on 3 January. The standard curve should be drawn to ensure the appropriateness of the correlation coefficient $(\geq 0.999)$ and the accuracy of the sample retention time and response value. 
The minimum detection limit of AIM was 0.004 ppbv. Other detailed information can be found in the work of Wang et al. (2019).

\section{Results and discussion}

\subsection{Temporal variations of meteorological parameters and pollutants}

The daily changes in the meteorological parameters and $\mathrm{PM}_{2.5}$ are shown in Fig. 1. In accordance with the daily average concentration level of $\mathrm{PM}_{2.5}$, the analysis and measurement process was divided into three periods (clean days - CDs, polluted days - PDs, and severely polluted days SPDs). The days on which the daily averages of $\mathrm{PM}_{2.5}$ were lower than the daily average of the second grade of the Chinese National Ambient Air Quality Standards (CNAAQS;

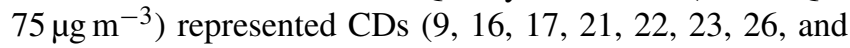
31 January), with RH ranging from $5 \%$ to $79 \%$ and WS ranging from 0 to $4.2 \mathrm{~m} \mathrm{~s}^{-1}$. The days on which the daily averages of $\mathrm{PM}_{2.5}$ were between 75 and $115 \mu \mathrm{g} \mathrm{m}^{-3}$ represented PDs $(10,15,18,20,25,27$, and 28 January), with $\mathrm{RH}$ ranging from $17 \%$ to $86 \%$ and WS ranging from 0 to $4.6 \mathrm{~m} \mathrm{~s}^{-1}$. The days on which the daily averages of $\mathrm{PM}_{2.5}$ were higher than $115 \mathrm{\mu g} \mathrm{m}^{-3}$ represented SPDs $(11,12,13$, $14,19,24,29$, and 30 January), with RH ranging from $30 \%$ to $96 \%$ and WS ranging from 0 to $3.5 \mathrm{~m} \mathrm{~s}^{-1}$. Northwesterly or easterly wind was observed in most of the observation periods, except for 21-22 January. WD was northerly, the maximum WS reached $4 \mathrm{~m} \mathrm{~s}^{-1}$, the $\mathrm{PM}_{2.5}$ concentration decreased rapidly, and the effect of pollutant removal was evident. Table 1 lists the data statistics of $\mathrm{HONO}, \mathrm{PM}_{2.5}, \mathrm{NO}_{2}$, $\mathrm{NO}, \mathrm{NO}_{x}, \mathrm{HONO} / \mathrm{NO}_{2}, \mathrm{HONO} / \mathrm{NO}_{x}, \mathrm{O}_{3}, \mathrm{CO}, T, \mathrm{RH}, \mathrm{WS}$, and WD during the measurement period, together with the mean value \pm standard deviation. The meteorological parameters in Table 1 show that the average $\mathrm{RH}$ in $\mathrm{CD}, \mathrm{PD}$, and SPD periods was $33 \%, 49 \%$, and $68 \%$, respectively. In SPDs, RH was high and WD was low (mean value of $0.4 \mathrm{~m} \mathrm{~s}^{-1}$ ).

In accordance with the data on trace gases, the average HONO values in CD, $\mathrm{PD}$, and SPD periods were 1.1, 2.3, and $3.7 \mathrm{ppbv}$, respectively. The mean values of $\mathrm{NO}_{2}$ were 25,33 , and $42 \mathrm{ppbv}\left(46,63\right.$, and $78 \mu \mathrm{g} \mathrm{m}^{-3}$ lower than the first grade of the CNAAQS; [ $\left.80 \mathrm{~g} \mathrm{~m}^{-3}\right]$ ), respectively. The mean values of $C O$ were 1,1 , and 2 ppmv $\left(1,2\right.$, and $2 \mathrm{mg} \mathrm{m}^{-3}$ lower than the first grade of the CNAAQS; $\left[4 \mathrm{mg} \mathrm{m}^{-3}\right]$ ), respectively. Figure 2 shows the concentration changes in HONO and gas species throughout the measurement period. The variations of the average $\mathrm{HONO}, \mathrm{PM}_{2.5}, \mathrm{NO}_{2}$, and $\mathrm{CO}$ in the three periods were similar. The mean values of all pollutant concentrations, except $\mathrm{O}_{3}$, in the SPDs period were the largest, and those values in the CDs period were the smallest. The highest mean value of $\mathrm{O}_{3}$ occurred in the CDs period, which is similar to previous observations (Hou et al., 2016; Huang et al., 2017; Zhang et al., 2019).

The HONO concentrations ranged from 0.2 to $14.8 \mathrm{ppbv}$ and had an average of $2.5 \mathrm{ppbv}$, which is higher than the average values of 0.6 (Rappenglück et al., 2013), 1.5 (Hou et al., 2016), and 1.0 ppbv (Huang et al., 2017) in previous urban studies. The diurnal variations of HONO during the measurement were similar in the three periods, as shown in Figs. 3 and 4. The diurnal variations of $\mathrm{HONO}, \mathrm{NO}, \mathrm{NO}_{2}$, $\mathrm{O}_{3}, \mathrm{HONO} / \mathrm{NO}_{2}$, and $\mathrm{HONO} / \mathrm{NO}_{x}$ are illustrated in Fig. 4. The error bars of Fig. 4 were placed separately in the tables of the Supplement (Table S2). After sunset, the HONO concentrations in CD, PD, and SPD periods began to accumulate due to the attenuation of solar radiation and the stabilization of the boundary layer (Cui et al., 2018). The maximum values of $1.7,4.1$, and $6.9 \mathrm{ppbv}$ were reached in the morning (08:00-10:00 LT) in CD, PD, and SPD periods, respectively. After 10:00 LT, the HONO concentration decreased because of the increased solubility and rapid photolysis, which remained at a low level before sunset (14:00-16:00 LT). The NO concentration decreased rapidly in the forenoon and remained low in the afternoon. After sunset, the concentrations of $\mathrm{NO}$ and $\mathrm{NO}_{2}$ began to increase and remained at a higher level than during the daytime. Furthermore, the diurnal variation of $\mathrm{NO}$ in the $\mathrm{CDs}$ period was similar to that of $\mathrm{NO}_{2}$. The peak was reached at around 09:00 LT due to vehicle emissions in the morning rush hours, and the lowest value was observed at around 16:00 LT. After 18:00 LT, the boundary layer height decreased in the evening rush hours, resulting in an increase in $\mathrm{NO}$ and $\mathrm{NO}_{2}$ concentrations (Hendrick et al., 2014). $\mathrm{O}_{3}$ showed a diurnal cycle and had maximum values in $\mathrm{CD}, \mathrm{PD}$, and $\mathrm{SPD}$ periods in the afternoon. The $\mathrm{HONO} / \mathrm{NO}_{2}$ ratio is commonly used to estimate the formation of $\mathrm{HONO}$ in $\mathrm{NO}_{2}$ transformation (Wang et al., 2013). Compared to $\mathrm{HONO}$ formation, $\mathrm{NO}_{2}$ transformation is less affected by the migration of atmospheric air mass during atmospheric migration ( $\mathrm{Li}$ et al., 2012). The $\mathrm{HONO} / \mathrm{NO}_{2}$ ratio in the CDs period began to increase after sunset and reached its peak at night. Then, it decreased in the morning as a result of the enhancement of $\mathrm{NO}_{2}$ emissions and photolysis of HONO. However, the mean value of $\mathrm{HONO} / \mathrm{NO}_{2}$ in PD and SPD periods gradually increased from the nighttime level and eventually reached the maximum values of $14.3 \%$ and $18.9 \%$ at 09:00 and 10:00 LT, respectively. The average $\mathrm{HONO} / \mathrm{NO}_{x}$ ratio $(4.9 \%)$ was more than twice the assumed globally averaged value (2.0\%; Elshorbany et al., 2014). This result indicates that the strength of the heterogeneous reaction increased slightly with the exacerbation of pollution. The $\mathrm{HONO} / \mathrm{NO}_{2}$ ratio showed a diurnal cycle with a low level in the afternoon and a high level after sunset due to the heterogeneous reaction of $\mathrm{NO}_{2}$ on the ground and aerosol surfaces (Su et al., 2008b). For comparison, the daytime and nighttime $\mathrm{HONO}, \mathrm{HONO} / \mathrm{NO}_{2}$, and $\mathrm{HONO} / \mathrm{NO}_{x}$ mean values in other cities around the world are listed in $\mathrm{Ta}-$ ble 2. The values of $\mathrm{HONO}, \mathrm{HONO} / \mathrm{NO}_{2}$, and $\mathrm{HONO} / \mathrm{NO}_{x}$ 


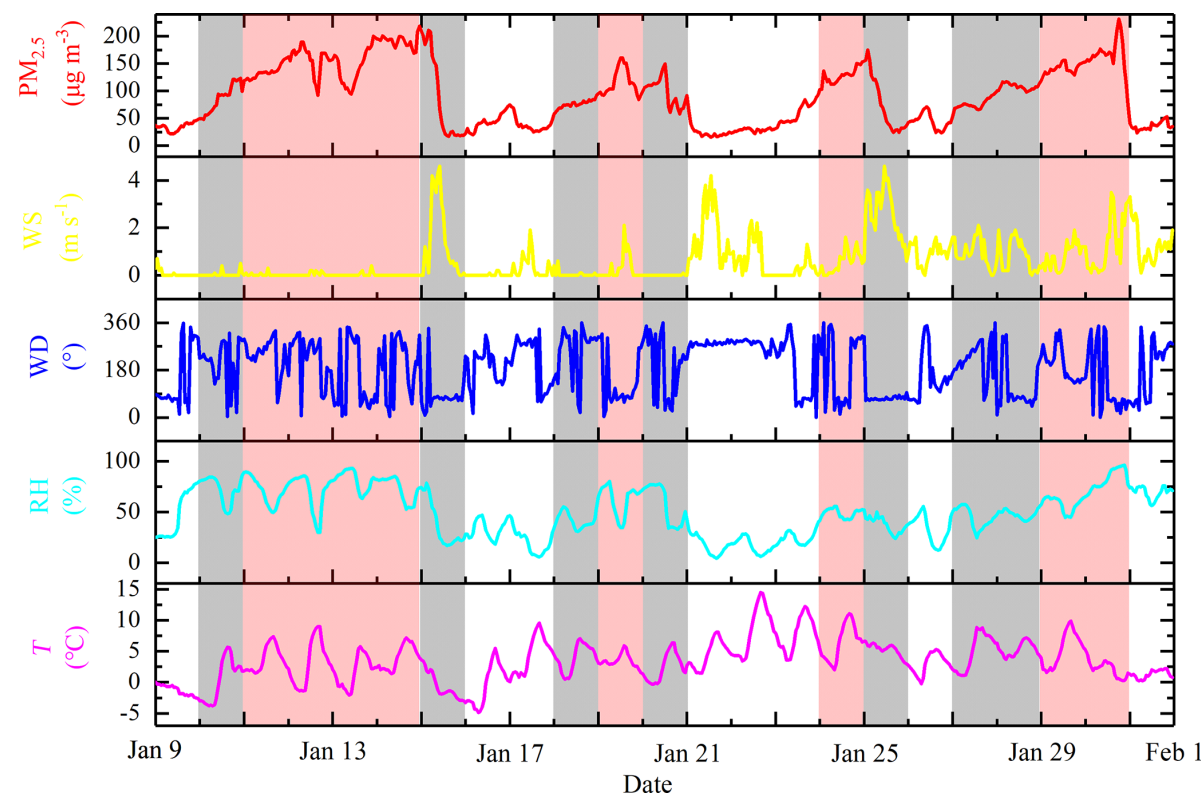

Figure 1. Temporal trends of hourly averages for $T$, RH, WD, WS, and $\mathrm{PM}_{2.5}$ during the measurement. (The shaded areas are as follows: white for the CDs period; gray for the PDs period; and red for the SPDs period.)

Table 1. Data statistics of $\mathrm{HONO}, \mathrm{PM}_{2.5}, \mathrm{NO}_{2}, \mathrm{NO}, \mathrm{NO}_{x}, \mathrm{HONO} / \mathrm{NO}_{2}, \mathrm{HONO} / \mathrm{NO}_{x}, \mathrm{O}_{3}, \mathrm{CO}, T$, RH, and WS during the measurement period; mean value \pm standard deviation.

\begin{tabular}{|c|c|c|c|c|c|c|c|c|c|c|}
\hline \multirow[t]{2}{*}{ Trace gases } & \multicolumn{3}{|c|}{ CDs } & \multicolumn{3}{|c|}{ PDs } & \multicolumn{3}{|c|}{ SPDs } & \multirow{2}{*}{$\begin{array}{l}\text { Total } \\
\text { days }\end{array}$} \\
\hline & Day & Night & All & Day & Night & All & Day & Night & All & \\
\hline $\mathrm{PM}_{2.5}\left(\mu \mathrm{g} \mathrm{m}^{-3}\right)$ & $37 \pm 15$ & $41 \pm 17$ & $39 \pm 16$ & $80 \pm 32$ & $93 \pm 46$ & $87 \pm 40$ & $148 \pm 29$ & $147 \pm 33$ & $147 \pm 31$ & $91 \pm 54$ \\
\hline HONO (ppbv) & $0.9 \pm 0.7$ & $1.4 \pm 0.7$ & $1.1 \pm 0.7$ & $1.9 \pm 1.7$ & $2.7 \pm 1.3$ & $2.3 \pm 1.5$ & $3.5 \pm 2.7$ & $4.0 \pm 1.1$ & $3.7 \pm 2.1$ & $2.5 \pm 1.9$ \\
\hline $\mathrm{CO}(\mathrm{ppmv})$ & $1 \pm 0.3$ & $1 \pm 0.3$ & $1 \pm 0.3$ & $1 \pm 0.4$ & $1 \pm 0.6$ & $1 \pm 0.5$ & $2 \pm 0.6$ & $2 \pm 0.4$ & $2 \pm 0.5$ & $1 \pm 0.6$ \\
\hline NO (ppbv) & $18.4 \pm 39.3$ & $15 \pm 34.3$ & $16.7 \pm 36.8$ & $20.3 \pm 26.2$ & $30.7 \pm 33.6$ & $25.5 \pm 30.4$ & $40.8 \pm 50.8$ & $64.3 \pm 82.1$ & $52.5 \pm 68.9$ & $31.8 \pm 51.4$ \\
\hline $\mathrm{NO}_{2}$ (ppbv) & $23 \pm 13$ & $26 \pm 13$ & $25 \pm 13$ & $29 \pm 9$ & $38 \pm 10$ & $33 \pm 11$ & $40 \pm 11$ & $43 \pm 10$ & $42 \pm 11$ & $33 \pm 14$ \\
\hline $\mathrm{O}_{3}(\mathrm{ppbv})$ & $21.4 \pm 11.5$ & $13.8 \pm 10.0$ & $17.6 \pm 11.4$ & $17.4 \pm 11.9$ & $8.9 \pm 8.1$ & $13.1 \pm 10.9$ & $15.6 \pm 14.2$ & $7.9 \pm 7.1$ & $11.8 \pm 11.8$ & $14.2 \pm 11.7$ \\
\hline $\mathrm{HONO} / \mathrm{NO}_{2}(\%)$ & $4.2 \pm 3.6$ & $5.3 \pm 2.2$ & $4.7 \pm 3.1$ & $6.8 \pm 5.8$ & $7.4 \pm 3.9$ & $7.1 \pm 4.9$ & $9.0 \pm 7.7$ & $9.8 \pm 5.8$ & $9.4 \pm 6.8$ & $7.6 \pm 6.4$ \\
\hline $\mathrm{HONO} / \mathrm{NO}_{x}(\%)$ & $3.3 \pm 2.7$ & $6.0 \pm 5.6$ & $4.5 \pm 4.5$ & $4.4 \pm 2.5$ & $4.6 \pm 1.7$ & $4.5 \pm 2.1$ & $5.3 \pm 3.4$ & $5.8 \pm 4.7$ & $5.6 \pm 4.1$ & $4.9 \pm 3.8$ \\
\hline $\mathrm{RH}(\%)$ & $30 \pm 21$ & $36 \pm 20$ & $33 \pm 21$ & $44 \pm 17$ & $54 \pm 18$ & $49 \pm 18$ & $64 \pm 18$ & $73 \pm 13$ & $68 \pm 16$ & $50 \pm 24$ \\
\hline $\mathrm{WS}\left(\mathrm{m} \mathrm{s}^{-1}\right)$ & $0.8 \pm 1.0$ & $0.5 \pm 0.7$ & $0.7 \pm 0.9$ & $1.1 \pm 1.4$ & $0.6 \pm 0.9$ & $0.9 \pm 1.2$ & $0.4 \pm 0.7$ & $0.3 \pm 0.6$ & $0.4 \pm 0.7$ & $0.6 \pm 0.9$ \\
\hline$T\left(^{\circ}\right)$ & $4.3 \pm 4.6$ & $2.7 \pm 3.6$ & $3.5 \pm 4.2$ & $3.7 \pm 3.3$ & $2.6 \pm 3.1$ & $3.1 \pm 3.2$ & $4.6 \pm 3.2$ & $2.9 \pm 2.1$ & $3.8 \pm 2.8$ & $3.5 \pm 3.5$ \\
\hline
\end{tabular}

in Zhengzhou are relatively higher than those in other parts of the world. The reason for this phenomenon is that Zhengzhou is a high- $\mathrm{NO}_{x}$ area that provides HONO with abundant precursors ( $\mathrm{NO}_{2}$ and $\mathrm{NO}$ ) in winter (Kim et al., 2015).

\subsection{Nocturnal HONO sources and formation}

\subsubsection{Homogeneous reaction of $\mathrm{NO}$ and $\mathrm{OH}$}

The homogeneous reaction of $\mathrm{NO}$ and $\mathrm{OH}$ (reactions $\mathrm{R} 2$ and R3) is the main pathway of HONO formation in the gas phase. Spataro et al. (2013) found that the formation mechanism leads to an increase in HONO in high-pollution areas and an increase in $\mathrm{NO}$ at night. $P_{\mathrm{OH}+\mathrm{NO}}^{\text {net }}$ can be understood as the net hourly HONO production amount of the homoge- neous reaction and is calculated as follows:

$$
\begin{aligned}
& P_{\mathrm{OH}+\mathrm{NO}}^{\text {net }}=k_{\mathrm{OH}+\mathrm{NO}}[\mathrm{OH}][\mathrm{NO}] \\
& -k_{\mathrm{OH}+\mathrm{HONO}}[\mathrm{OH}][\mathrm{HONO}] \text {. }
\end{aligned}
$$

At $T=298 \mathrm{~K}$ and $P=101 \mathrm{kPa}$, the rate constants of $k_{\mathrm{OH}+\mathrm{NO}}$ and $k_{\mathrm{OH}+\mathrm{HONO}}$ are $9.8 \times 10^{-12}$ and $6.0 \times$ $10^{-12} \mathrm{~cm}^{3}$ molec. $^{-1} \mathrm{~s}^{-1}$, respectively (Atkinson et al., 2004; Sander et al., 2003). [OH] is the concentration of $\cdot \mathrm{OH}$ that was not measured during the campaign. Tan et al. (2018) found that, during the field measurement, the average concentration of $\cdot \mathrm{OH}$ in Beijing at nighttime was about $2.5 \times$ $10^{5}$ molec. $\mathrm{cm}^{-3}$. Moreover, the same $\cdot \mathrm{OH}$ concentration was also used to calculate the homogeneous reaction of HONO in the recent research of Beijing (Zhang et al., 2019), Shanghai (Cui et al., 2018), and Xi'an (Huang et al., 2017). Nighttime $\mathrm{OH}$ concentration increased as the latitude de- 


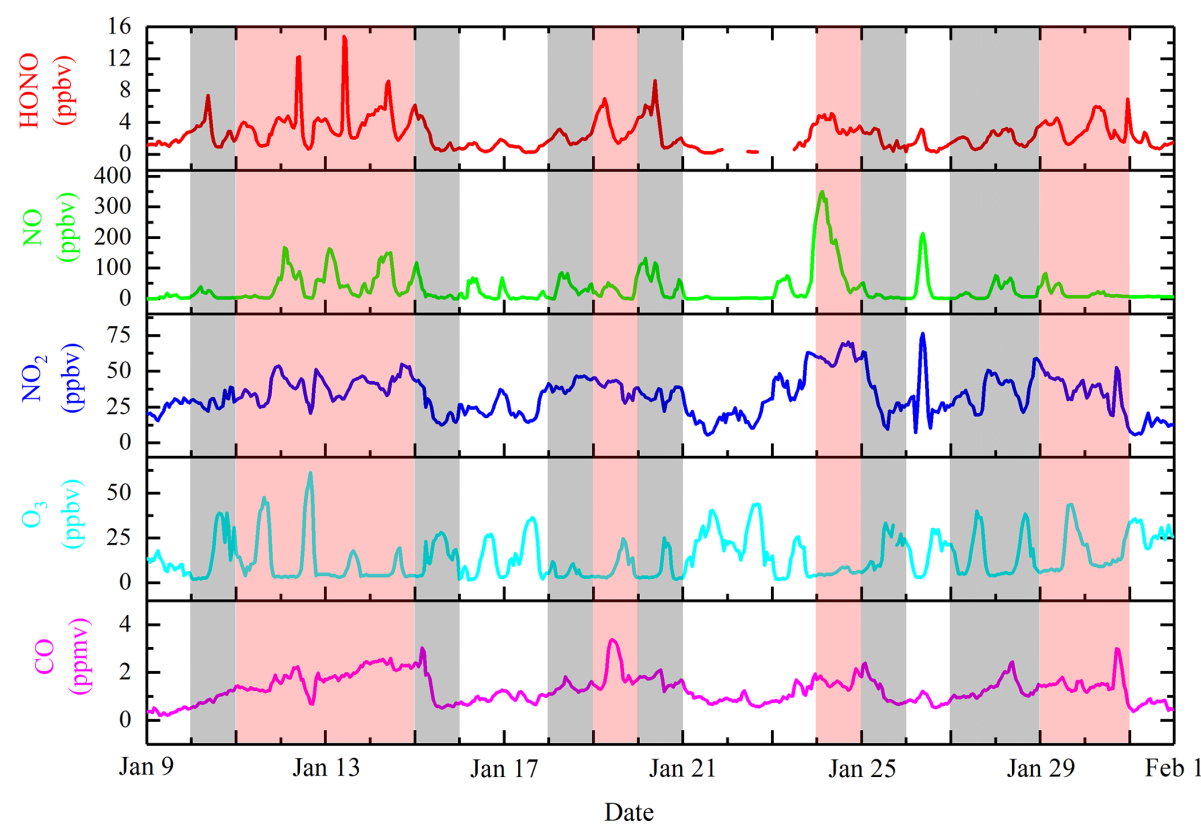

Figure 2. Temporal variations of hourly averages for $\mathrm{HONO}, \mathrm{NO}, \mathrm{NO}_{2}, \mathrm{O}_{3}$, and $\mathrm{CO}$ during the measurement. (The shaded areas are as follows: white for the CDs period; gray for the PDs period; and red for the SPDs period.)

Table 2. Comparisons of the daytime and nighttime $\mathrm{HONO}$ level, $\mathrm{HONO} / \mathrm{NO}_{2}$, and $\mathrm{HONO} / \mathrm{NO}_{x}$ mean values in Zhengzhou and other sites around the world.

\begin{tabular}{|c|c|c|c|c|c|c|c|c|c|}
\hline \multirow[t]{2}{*}{ Date (site) } & \multirow[t]{2}{*}{ Instrument } & \multicolumn{3}{|c|}{$\begin{array}{l}\text { HONO } \\
(\mathrm{ppbv})\end{array}$} & \multicolumn{2}{|c|}{$\begin{array}{c}\mathrm{HONO} / \mathrm{NO}_{2} \\
(\%)\end{array}$} & \multicolumn{2}{|c|}{$\begin{array}{c}\mathrm{HONO} / \mathrm{NO}_{x} \\
(\%)\end{array}$} & \multirow[t]{2}{*}{ Reference } \\
\hline & & Day & Night & N/D & Day & Night & Day & Night & \\
\hline $\begin{array}{l}\text { October-November } 2014 \\
\text { (Beijing, urban) }\end{array}$ & $\begin{array}{l}\text { LOPAP (long path } \\
\text { absorption photometer) }\end{array}$ & 0.9 & 1.8 & 2.0 & 2.6 & 4.6 & 1.7 & 2.2 & Tong et al. (2015) \\
\hline \multirow[t]{2}{*}{$\begin{array}{l}\text { February-March } 2014 \\
\text { (Beijing, urban) }\end{array}$} & \multirow[t]{2}{*}{ LOPAP } & \multicolumn{6}{|c|}{ (Severe haze) } & 2.5 & Hou et al. (2016) \\
\hline & & 0.5 & 0.9 & 1.8 & $\begin{array}{c}7.8 \\
(\text { Clean }\end{array}$ & 3.0 & 5.1 & 2.4 & \\
\hline $\begin{array}{l}\text { July } 2006 \\
\text { (Guangzhou, rural) }\end{array}$ & LOPAP & 0.2 & 0.9 & 4.5 & 1.0 & 2.5 & 4.3 & 4.5 & Li et al. (2012) \\
\hline $\begin{array}{l}\text { July } 2014-\text { August } 2015 \\
\text { (Xi'an, urban) }\end{array}$ & LOPAP & 0.5 & 1.6 & 3.2 & 3.3 & 6.2 & & & Huang et al. (2017) \\
\hline $\begin{array}{l}\text { August 2010-June } 2012 \\
\text { (Shanghai, urban) }\end{array}$ & Active DOAS & 0.8 & 1.1 & 1.4 & 4.2 & 4.5 & & & Wang et al. (2013) \\
\hline $\begin{array}{l}\text { July } 2009 \\
\text { (Paris, urban) }\end{array}$ & $\begin{array}{l}\text { Wet chemical derivatization } \\
\text { technique HPLC/UV-VIS } \\
\text { detection }\end{array}$ & 0.1 & 0.2 & 2.0 & 3.3 & 2.5 & & & Michoud et al. (2014) \\
\hline January 2019 & AIM & 2.2 & 2.8 & 1.3 & 6.8 & 8.5 & 4.4 & 5.5 & This study \\
\hline
\end{tabular}




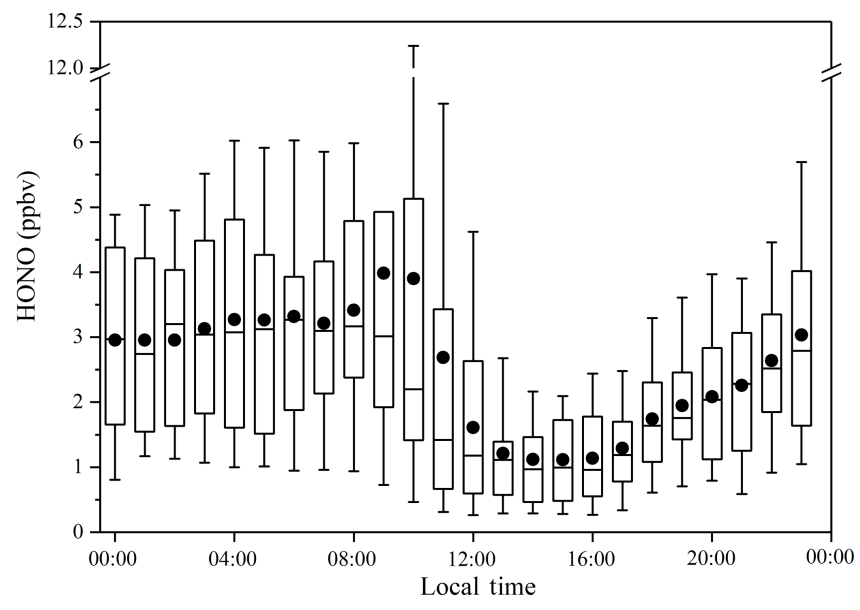

Figure 3. Diurnal variations of HONO during the measurement.

creases ranged from 3 to $6 \times 10^{5}$ molec. $\mathrm{cm}^{-3}$ (Lelieveld et al., 2016). Zhengzhou has a lower latitude than Beijing, so the concentration of $\mathrm{OH}$ used in this study is $2.5 \times$ $10^{5}$ molec. $\mathrm{cm}^{-3} \cdot P_{\mathrm{OH}+\mathrm{NO}}^{\mathrm{net}}$ primarily depends on the concentrations of $\mathrm{NO}$ and HONO because the values of $k_{\mathrm{OH}+\mathrm{NO}}$ and $k_{\mathrm{OH}+\mathrm{HONO}}$ are close. Figure 5 shows the nocturnal variations of $P_{\mathrm{OH}+\mathrm{NO}}^{\text {net }}, \mathrm{NO}$, and $\mathrm{HONO}$ during $\mathrm{CD}, \mathrm{PD}$, and $\mathrm{SPD}$ periods. The uncertainties of $P_{\mathrm{OH}+\mathrm{NO}}^{\text {net }}, \mathrm{NO}$, and $\mathrm{HONO}$ in Fig. 5 are shown in Table S3. When the NO levels were high, the variations of $P_{\mathrm{OH}+\mathrm{NO}}^{\text {net }}$ followed those of NO during the three periods (Atkinson et al., 2004). The mean value of $P_{\mathrm{OH}+\mathrm{NO}}^{\text {net }}$ was $0.33 \mathrm{ppbv} \mathrm{h}^{-1}$, and the specific values in $\mathrm{CD}$, $\mathrm{PD}$, and SPD periods were $0.13,0.26$, and $0.56 \mathrm{ppbv} \mathrm{h}^{-1}$, respectively. We assumed $\pm 50 \% \cdot \mathrm{OH}$ values to estimate the uncertainty of $P_{\mathrm{OH}+\mathrm{NO}}^{\text {net }}$. The $\cdot \mathrm{OH}$ values of $1.25 \times 10^{5}$ and $3.75 \times 10^{5}$ molec. $\mathrm{cm}^{-3}$ were calculated for the $P_{\mathrm{OH}+\mathrm{NO}}^{\text {net }}$ values of 0.16 and $0.49 \mathrm{ppbv} \mathrm{h}^{-1}$.

$P_{\mathrm{OH}+\mathrm{NO}}^{\text {net }}$ varied from 0.01 to $0.47 \mathrm{ppbvh}^{-1}$ during the CDs period. The mean value of $P_{\mathrm{OH}+\mathrm{NO}}^{\text {net }}$ increased before midnight, decreased after midnight, and increased slightly at 03:00 LT. In the PDs period, $P_{\mathrm{OH}+\mathrm{NO}}^{\text {net }}$ ranged from 0.07 to $0.44 \mathrm{ppbv} \mathrm{h}^{-1}$. The situation was similar to that of the CDs period, except that the value remained almost constant. In addition, the contribution of HONO from homogeneous reactions during the SPDs period was larger than those in the $\mathrm{CD}$ and $\mathrm{PD}$ periods, and the level of $P_{\mathrm{OH}+\mathrm{NO}}^{\text {net }}$, with an average value of $0.56 \mathrm{ppbv} \mathrm{h}^{-1}$, was lower than the value in a previous study $\left(2.18 \mathrm{ppbvh}^{-1}\right.$ in Beijing; Tong et al., 2015). From 19:00 to 03:00 LT, the mean value of $P_{\mathrm{OH}+\mathrm{NO}}^{\text {net }}$ increased from 0.15 to $0.9 \mathrm{ppbv} \mathrm{h}^{-1}$. HONO increased from 2.84 to $4.59 \mathrm{ppbv}$ and subsequently decreased to $4.43 \mathrm{ppbv}$. By integrating $P_{\mathrm{OH}+\mathrm{NO}}^{\text {net }}$ during the $8 \mathrm{~h}$ period, the homogeneous reaction can provide an accumulated HONO formation of at least $3.36 \mathrm{ppbv}$ (i.e., $0.15+0.20+0.25+0.25+$ $0.35+0.56+0.7+0.9 \mathrm{ppbv})$. However, the mean accumulation value of measured $\mathrm{HONO}$ in this nighttime period was merely $1.59 \mathrm{ppbv}$. With the increase in pollution levels, the HONO accumulation period at nighttime increased. This result indicates that, first, the homogeneous reaction of $\mathrm{OH}+\mathrm{NO}$ is sufficient to augment HONO in the first half of the night, although $\mathrm{NO}_{2}$ transformation and other sources may still exist. When the concentration of NO is relatively high, the net production generated by $\mathrm{OH}+\mathrm{NO}$ may be the leading factor of the increase in HONO at night (Tong et al., 2015). Second, the hourly level of HONO abatement pathways, except $\mathrm{OH}+\mathrm{HONO}$, should be at least $0.22 \mathrm{ppbv} \mathrm{h}^{-1}$ (i.e., 3.36-1.59 ppbv $(8 \mathrm{~h})^{-1}$ ). This phenomenon may arise because the dry deposition on ground surfaces can be the main HONO removal pathway at night, which is similar to a previous study (Li et al., 2012).

\subsubsection{Direct emission}

At present, no HONO emission inventory or emission factor database is available for Zhengzhou. As a result, estimating any HONO from direct emissions is difficult. In the current study, directly emitted HONO could have been generated by vehicle exhaust emissions and biomass combustion because the site is close to the West Fourth Ring expressway of Zhengzhou and Lian Huo Expressway in the north. Hence, only night data (17:00-06:00 LT) were considered to avoid the problem of instant photolysis of directly emitted HONO. In a previous study, the $\mathrm{HONO} / \mathrm{NO}_{x}$ ratio from tunnel measurement was set to $0.65 \%$ to estimate an upper limit of HONO emitted by traffic near the site (Kurtenbach et al., 2001). The minimum value of $\mathrm{HONO} / \mathrm{NO}_{x}$ in the SPDs period in the current work was $1.5 \%$, which is slightly higher than the value measured in the abovementioned study. HONO emitted directly at night was not transformed immediately. The HONO concentrations corrected by direct emissions are given as follows:

$$
\begin{aligned}
{[\mathrm{HONO}]_{\mathrm{correct}} } & =[\mathrm{HONO}]-[\mathrm{HONO}]_{\mathrm{emission}} \\
& =[\mathrm{HONO}]-0.0065 \times\left[\mathrm{NO}_{x}\right],
\end{aligned}
$$

where $[\mathrm{HONO}]_{\text {emission }},\left[\mathrm{NO}_{x}\right]$, and 0.0065 are the direct HONO emissions concentration, $\mathrm{NO}_{x}$ concentration, and $\mathrm{HONO} / \mathrm{NO}_{2}$ direct emissions ratio, respectively. The direct emissions contribution was estimated by comparing the direct emission HONO with the observed HONO. The ranges of $\mathrm{HONO}_{\text {emission }} / \mathrm{HONO}$ in $\mathrm{CD}, \mathrm{PD}$, and SPD periods were $2 \%-52 \%, 6 \%-34 \%$, and $2 \%-41 \%$, respectively, and the mean values were $17 \%, 16 \%$, and $16 \%$, respectively. The frequency distribution of the $\mathrm{HONO}_{\text {emission }} / \mathrm{HONO}$ ratio at nighttime is shown in Fig. 6. For this upper-limit estimation, the frequency distribution of $\mathrm{HONO}_{\text {emission} / \mathrm{HONO} \text { (less }}$ than $20 \%$ ) was approximately $77 \%$. Hence, direct emissions may not be the main reason for the high growth of HONO levels. Compared to the direct emissions of other sites, the emissions of the measurement site accounted for a lower proportion - possibly because the site is on the campus and relatively far from the highway. 

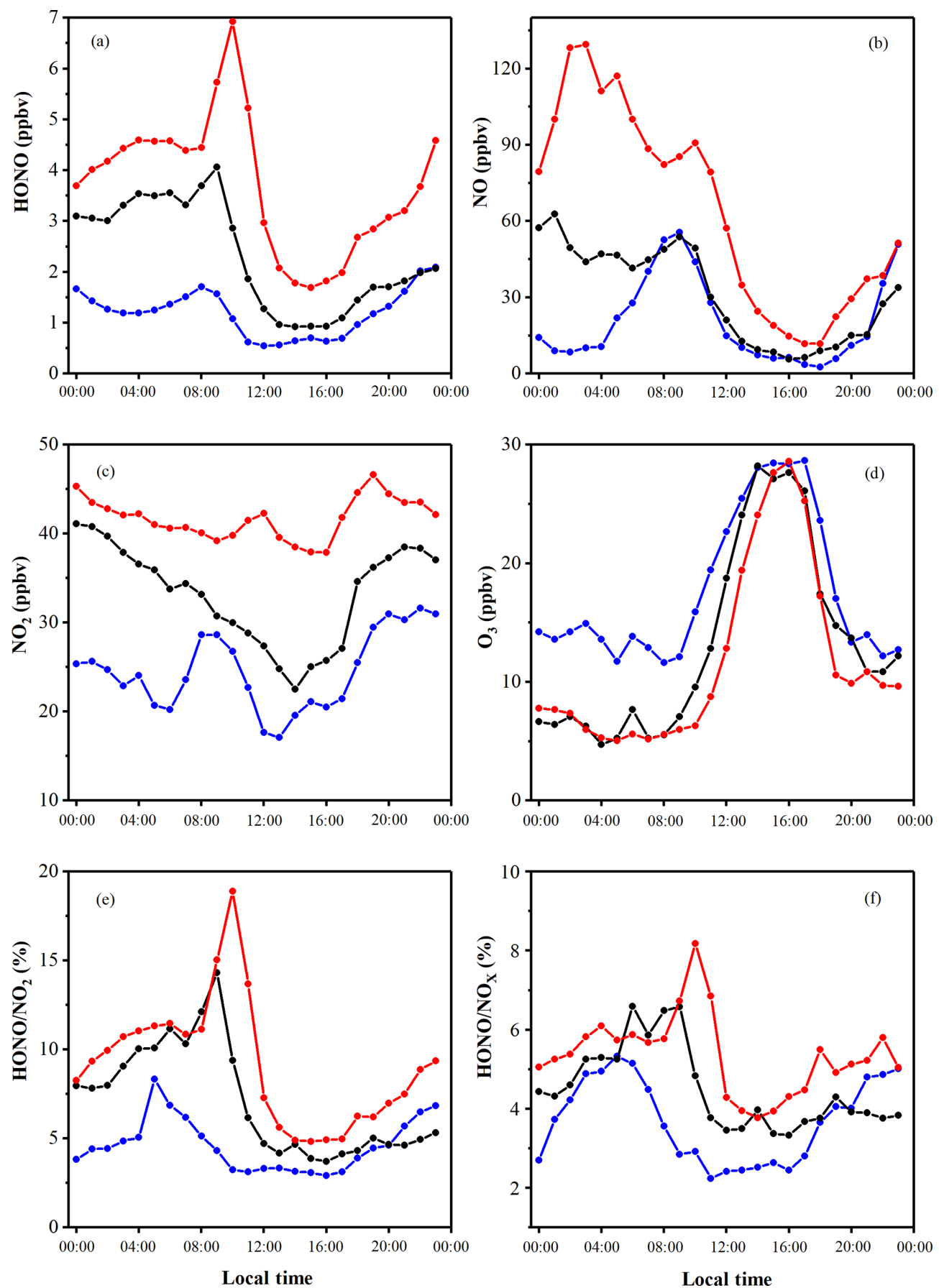

Figure 4. Diurnal variations of $\mathrm{HONO}, \mathrm{NO}, \mathrm{NO}_{2}, \mathrm{O}_{3}, \mathrm{HONO} / \mathrm{NO}_{2}$, and $\mathrm{HONO} / \mathrm{NO}_{x}$. The blue points and lines represent the CDs period; the black points and lines represent the PDs period; and the red points and lines represent the SPDs period.

\subsubsection{Heterogeneous conversion of $\mathrm{NO}_{2}$ to $\mathrm{HONO}$}

$\mathrm{NO}_{2}$ is an important precursor for $\mathrm{HONO}$ formation. In addition, recent field measurements in many urban locations have shown that a positive correlation exists between $\mathrm{HONO}$ and $\mathrm{NO}_{2}$ (Cui et al., 2018; Hao et al., 2006; Huang et al., 2017; Zhang et al., 2019), which suggests that they have a common source. Moreover, Acker et al. (2005) reported that different meteorological conditions may lead to significant differences in the relationship between the source and receptor, and these differences lead to various types of correlations. During the measurement period, the $\mathrm{HONO} / \mathrm{NO}_{2}$ ratio varied between $1.3 \%$ and $59.0 \%$, with an average of $7.6 \%$, which is slightly higher than the averaged value of $6.2 \%$ in a previous study 


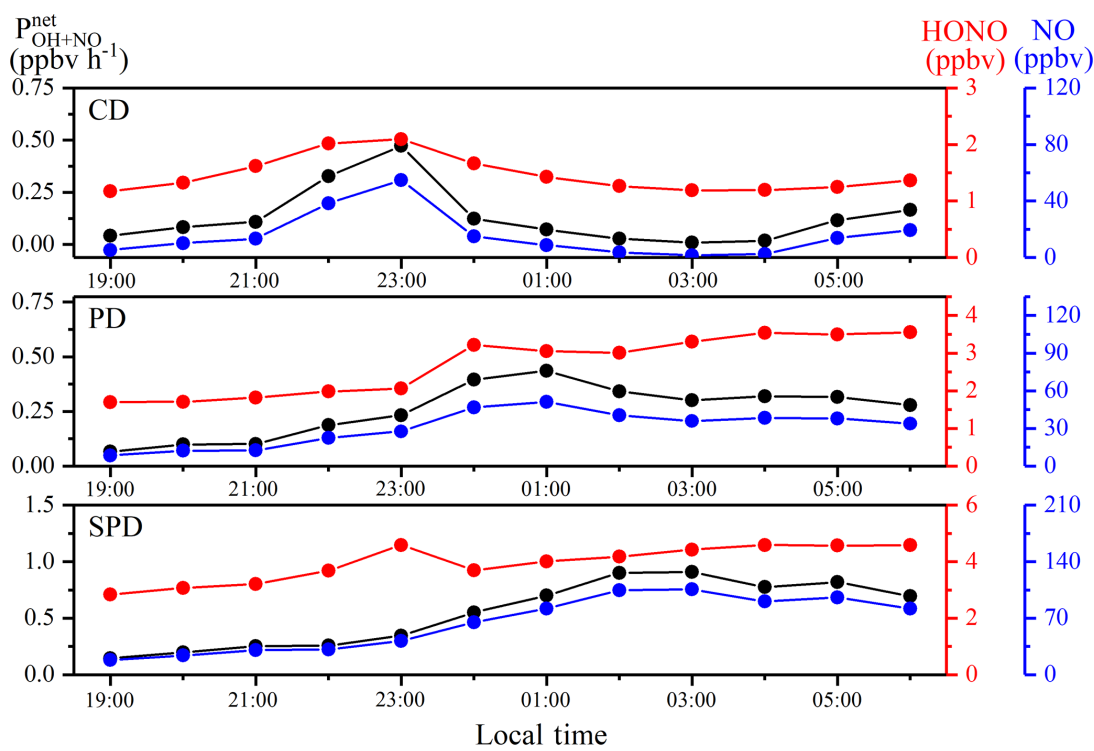

Figure 5. Nocturnal variations of $P_{\mathrm{OH}+\mathrm{NO}}^{\text {net }}, \mathrm{HONO}$, and $\mathrm{NO}$ during $\mathrm{CD}, \mathrm{PD}$, and $\mathrm{SPD}$ periods.

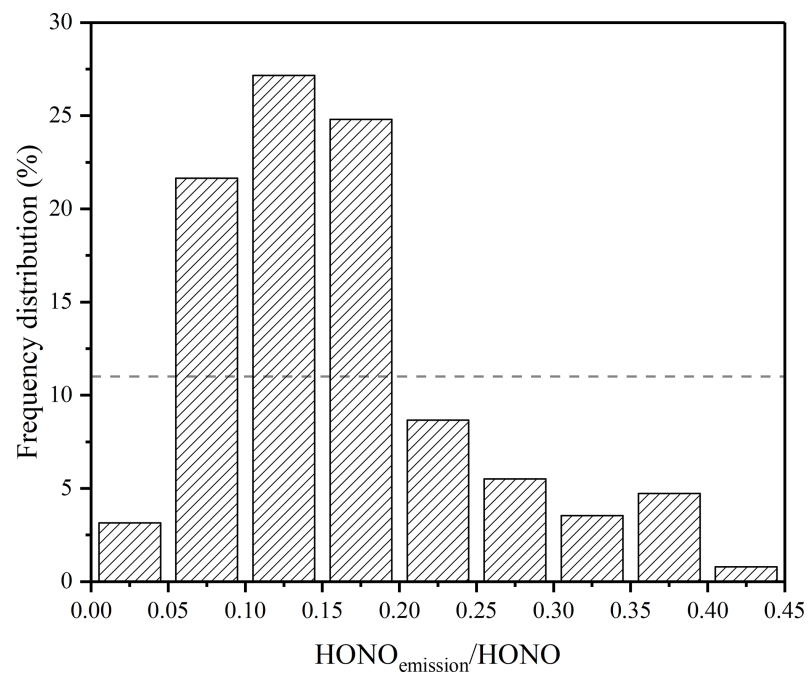

Figure 6. Percentage distribution of the nighttime

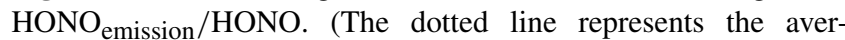
age of $\mathrm{HONO}_{\text {emission}} / \mathrm{HONO}$.)

(Cui et al., 2018). The $\mathrm{HONO} / \mathrm{NO}_{2}$ ratio calculated in this work is much larger than the ratio calculated for direct emissions ( $<1 \%$; Kurtenbach et al., 2001), suggesting that heterogeneous reactions may be a more important pathway for $\mathrm{HONO}$ production than direct emissions. With regard to the heterogeneous conversion of $\mathrm{NO}_{2}$, several studies (An et al., 2012; Shen and Zhang, 2013) reported that the surface of soot particles is the medium of $\mathrm{NO}_{2}$ conversion. The contribution of soot surface to HONO production is usually much lower than expected because the uptake efficiency of $\mathrm{NO}_{2}$ decreases with the prolonged reaction time caused by surface deactivation. The aerosol surface is an important medium for the heterogeneous transformation from $\mathrm{NO}_{2}$ to $\mathrm{HONO}$ (Liu et al., 2014). The mass concentration of aerosols was used as an alternative to identify the influence of aerosols in this study because the surface density of aerosols could not be obtained.

The correlations between $\mathrm{PM}_{2.5}$ and the $\mathrm{HONO} / \mathrm{NO}_{2}$ ratio in CD, PD, and SPD periods are shown in Fig. 7. With the exacerbation of the $\mathrm{PM}_{2.5}$ level, the average value of $\mathrm{HONO} / \mathrm{NO}_{2}$ gradually increased, indicating that the aerosol surface occupied an important position in the heterogeneous transformation. A comparison of $\mathrm{HONO} / \mathrm{NO}_{2}$ and HONO with $\mathrm{PM}_{2.5}$ showed that the correlation between $\mathrm{HONO} / \mathrm{NO}_{2}$ and $\mathrm{PM}_{2.5}\left(R^{2}=0.23\right)$ was weaker than that between $\mathrm{HONO}$ and $\mathrm{PM}_{2.5}\left(R^{2}=0.55\right)$ during the entire period. The main source of HONO could not have been the transformation of $\mathrm{NO}_{2}$. Notably, the HONO correlation in the PDs period was significantly stronger than that of the other two periods. This result proves that HONO-related reactions occurred more frequently during this period. The fair correlation between $\mathrm{HONO}$ and $\mathrm{PM}_{2.5}$ may pinpoint the mainly anthropogenic origins of these two pollutants with the high direct or indirect contribution of combustion sources. The reason for the increased HONO during the heavy pollution period could be due to the comparatively high loading and large particle surface (Cui et al., 2018). Similar phenomena have been observed in a correlation study on $\mathrm{CO}$ and $\mathrm{HONO}$ in which $\mathrm{CO}$ was used as a tracer for traffic-induced emissions and tested by considering the correlation between HONO and CO over an identical time interval (Qin et al., 2009). The correlation coefficient between HONO and CO was relatively moderate $\left(R^{2}=0.43\right)$, indicating that $\mathrm{HONO}$ and $\mathrm{CO}$ could come from the same source of emissions. Gen- 

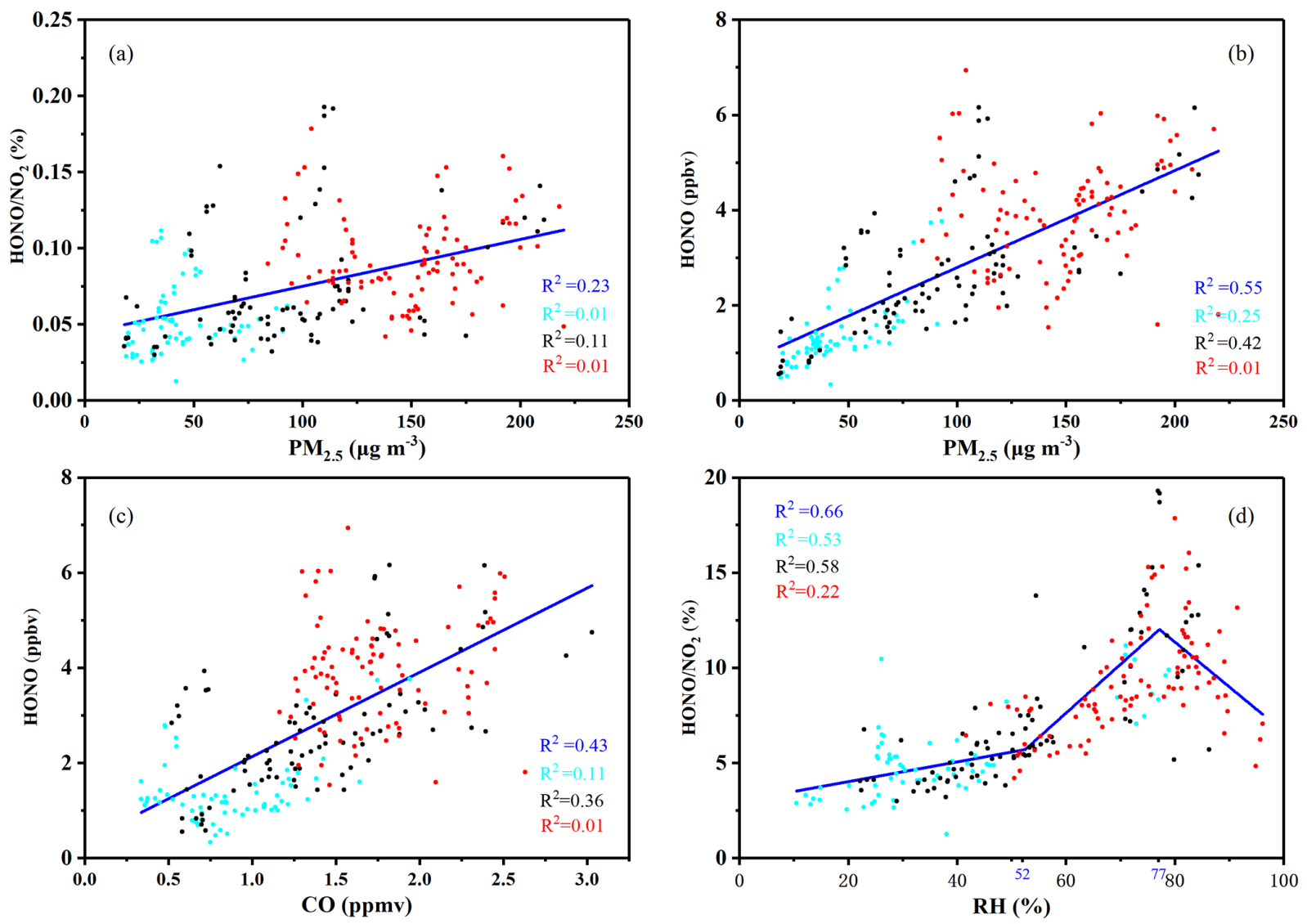

Figure 7. Nighttime correlation studies between $\mathrm{PM}_{2.5}$ and $\mathrm{HONO} / \mathrm{NO}_{2} ; \mathrm{PM}_{2.5}$ and $\mathrm{HONO}$; $\mathrm{CO}$ and $\mathrm{HONO}$; and $\mathrm{RH}$ and $\mathrm{HONO} / \mathrm{NO} 2$ during the entire measurement period - including the CD, PD, and SPD periods. The blue lines represent the full measurement period; the light blue points represent the CDs period; the black points represent the PDs period; and the red points represent the SPDs period.

erally speaking, $\mathrm{CO}$ and $\mathrm{NO}$ are mainly related to combustion processes such as vehicle emissions and fossil fuel and biomass combustion (Tong et al., 2016). Thus, fossil fuel and biomass combustion may contribute to HONO production, but they cannot be measured directly.

The absorbed water influences the heterogeneous formation (Stutz et al., 2004). The influence of RH on the heterogeneous conversion is shown in Fig. 7d. When RH was less, the $\mathrm{HONO} / \mathrm{NO}_{2}$ ratio slowly increased. When $\mathrm{RH}$ was increased, the $\mathrm{HONO} / \mathrm{NO}_{2}$ ratio began to increase rapidly with $\mathrm{RH}$. The $\mathrm{HONO} / \mathrm{NO}_{2}$ ratio decreased when $\mathrm{RH}$ reached a certain high level. Similar variation patterns have been observed in previous studies (Huang et al., 2017; Qin et al., 2009; Tong et al., 2015). Surface adsorbed water functions not only as the source but also as the sink of HONO by affecting the hydrolysis of $\mathrm{NO}_{2}$ and the sedimentation of $\mathrm{HONO}$ to generate HONO (Ammann et al., 1998). When RH ranged at the middle level, the heterogeneous conversion of $\mathrm{NO}_{2}$ to HONO was more significant than that of the deposition. This phenomenon confirms that RH improved the conversion efficiency (Stutz et al., 2004). However, the surface reached saturation when RH reached a certain high level. The excess wa- ter restricted $\mathrm{NO}_{2}$ transformation (Wojtal et al., 2011). The absorption and dissolution of $\mathrm{HONO}$ by the saturated surface water layer caused the $\mathrm{HONO} / \mathrm{NO}_{2}$ ratio to decrease drastically.

The correlation between $\mathrm{HONO}_{\text {correct }}$ and $\mathrm{NO}_{2}$ at nighttime is shown in Fig. S1. $\mathrm{HONO}_{\text {correct }}$ was used in the calculation to exclude the influence of direct emissions on $\mathrm{NO}_{2}$ conversion. The nocturnal variations of $\mathrm{HONO}_{\text {correct }}, \mathrm{NO}_{2}$, and $\mathrm{HONO}_{\text {correct }} / \mathrm{NO}_{2}$ ratios in the $\mathrm{CD}, \mathrm{PD}$, and SPD periods are presented in Fig. 8. The uncertainties of $\mathrm{HONO}_{\text {correct }}$, $\mathrm{NO}_{2}$, and $\mathrm{HONO}_{\text {correct }} / \mathrm{NO}_{2}$ ratios in Fig. 8 are shown in Table S4. In general, the $\mathrm{HONO}$ correct $/ \mathrm{NO}_{2}$ ratio reached its maximum at or before midnight but decreased after midnight. In the PD and SPD periods, HONO was generated by heterogeneous reaction (R4), and $\mathrm{NO}_{2}$ decreased after midnight. The production of $\mathrm{HONO}$ was equal to its loss (mainly night deposition), and the HONO concentration reached a relative balance. The weak correlation between nighttime $\mathrm{HONO} / \mathrm{NO}_{2}$ and $\mathrm{PM}_{2.5}$ can be reasonably explained by the stable $\mathrm{HONO}$ correct $/ \mathrm{NO}_{2}$ ratio after midnight (Qin et al., 2009). A previous study (Xu et al., 2015) found that a low $\mathrm{HONO}_{\text {correct }}$ in the first half of the night (19:00-00:00 LT) 


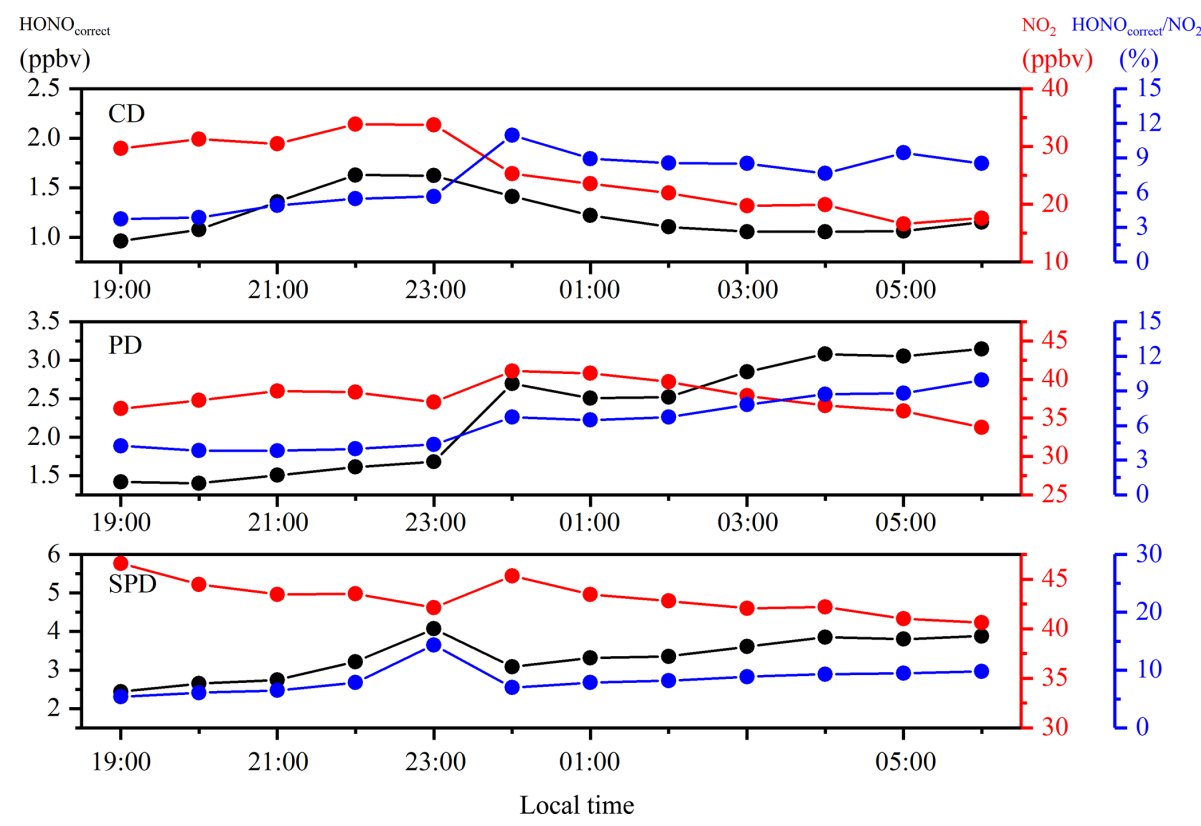

Figure 8. Nocturnal variations of $\mathrm{HONO}_{\text {correct }}, \mathrm{NO}_{2}$, and $\mathrm{HONO}_{\text {correct }} / \mathrm{NO}_{2}$ in $\mathrm{CD}, \mathrm{PD}$, and SPD periods.

indicates the important contribution of automobile exhaust emissions, and a low $\mathrm{HONO}_{\text {correct }}$ in the second half of the night means heterogeneous reactions dominate. Therefore, the heterogeneous reaction conversion rate of HONO was calculated in the current study by using the data of $\mathrm{HONO}_{\text {correct }}$.

The conversion rate of HONO $\left(C_{\mathrm{HONO}}\right)$ is usually used as an indicator to test the efficiency of $\mathrm{NO}_{2}$ heterogeneous reactions. Total $\mathrm{HONO}_{\text {correct }}$ was assumed to be generated by the heterogeneous transformation of $\mathrm{NO}_{2}$. The formula for the conversion rate of $\mathrm{NO}_{2}\left(C_{\mathrm{HONO}}\right)$ is as follows ( $\mathrm{Su}$ et al., 2008a; Xu et al., 2015):

$C_{\mathrm{HONO}}=\frac{\left(\left[\mathrm{HONO}_{\text {correct }}\right]_{t 2}-\left[\mathrm{HONO}_{\text {correct }}\right]_{t 1}\right)}{(t 2-t 1)\left[\mathrm{NO}_{2}\right]}$,

where $\left[\mathrm{NO}_{2}\right]$ is the average concentration of $\mathrm{NO}_{2}$ within the $t 2-t 1$ time interval $(1 \mathrm{~h})$. In this study, the averaged conversion rate of $\mathrm{NO}_{2}$ was $1.02 \times 10^{-2} \mathrm{~h}^{-1}$. The mean values of $C_{\text {HONO }}$ in the CD, PD, and SPD periods were $0.72 \times 10^{-2}$, $0.64 \times 10^{-2}$, and $1.54 \times 10^{-2} \mathrm{~h}^{-1}$, respectively. The averaged conversion rates in this study were $0.58 \times 10^{-2}$ and $1.46 \times 10^{-2} \mathrm{~h}^{-1}$ higher than those of Beijing I (polluted) and II (heavily polluted) periods, respectively. The increase in the conversion rate demonstrates that $\mathrm{NO}_{2}$ had high reaction efficiency through the process from $\mathrm{NO}_{2}$ to $\mathrm{HONO}$ in the aggravation of pollution, which could have led to the high utilization efficiency of the aerosol surface. The exact uptake coefficients of $\mathrm{NO}_{2}$ on the ground and aerosol surfaces are variable and should be different (Harrison and Collins, 1998). The present analysis simplified this process by treating the ground and aerosol surfaces in the same way. The uptake co- efficient is mainly dependent on the surface characteristics, e.g., surface type and moisture (Lu et al., 2018).

\subsection{Daytime HONO budget}

The expression of $\mathrm{dHONO} / \mathrm{d} t$ represents the observed variations of hourly $\mathrm{HONO}$ concentrations, for which we can use $\Delta \mathrm{HONO} / \Delta t$ in the following way instead:

$$
\begin{aligned}
& \mathrm{dHONO} / \mathrm{d} t=\text { sources }- \text { sinks } \\
&=\left(P_{\text {unknown }}+P_{\mathrm{OH}+\mathrm{NO}}+P_{\mathrm{emi}}+P_{\text {het }}\right) \\
&-\left(L_{\mathrm{OH}+\mathrm{HONO}}+L_{\text {photo }}\right), \\
& P_{\mathrm{OH}+\mathrm{NO}}= k_{\mathrm{OH}+\mathrm{NO}[\mathrm{OH}][\mathrm{NO}],} \\
& L_{\mathrm{OH}+\mathrm{HONO}}=k_{\mathrm{OH}+\mathrm{HONO}}[\mathrm{OH}][\mathrm{HONO}] .
\end{aligned}
$$

The $\mathrm{dHONO} / \mathrm{d} t$ calculated from the measurements was small and evenly distributed at around zero (Li et al., 2012). $P_{\text {unknown }}$ is the production rate by an unknown daytime HONO source. $P_{\mathrm{OH}+\mathrm{NO}}$ is the rate of reaction of NO and $\mathrm{OH}$. $P_{\text {emi }}$ represents the direct emission rate of HONO from combustion processes. The daytime HONO budget was analyzed with Eq. (4) by studying the source and reduction ( $\mathrm{Su}$ et al., 2008b). The heterogeneous transformation mechanism was assumed to be the same for day and night. Therefore, the daytime heterogeneous productivity $\left(P_{\text {het }}=C_{\mathrm{HONO}} \times\right.$ $\left[\mathrm{NO}_{2}\right]$ ) was calculated with the nighttime mean values of $C_{\mathrm{HONO}}$ in different periods. $L_{\mathrm{OH}+\mathrm{HONO}}$ is the rate of the reaction between $\mathrm{OH}$ and $\mathrm{HONO}$ (reaction R3). The calculation formulas of $P_{\mathrm{OH}+\mathrm{NO}}$ and $L_{\mathrm{OH}+\mathrm{HONO}}$ have been provided in Sect. 3.2.1. Upon sunlight irradiation, $\cdot \mathrm{OH}$ and $\mathrm{NO}$ were formed as reaction R1. $L_{\text {photo }}$ represents the photolysis loss rate of $\mathrm{HONO}\left(L_{\text {photo }}=J_{\mathrm{HONO}} \times[\mathrm{HONO}]\right)$. The 

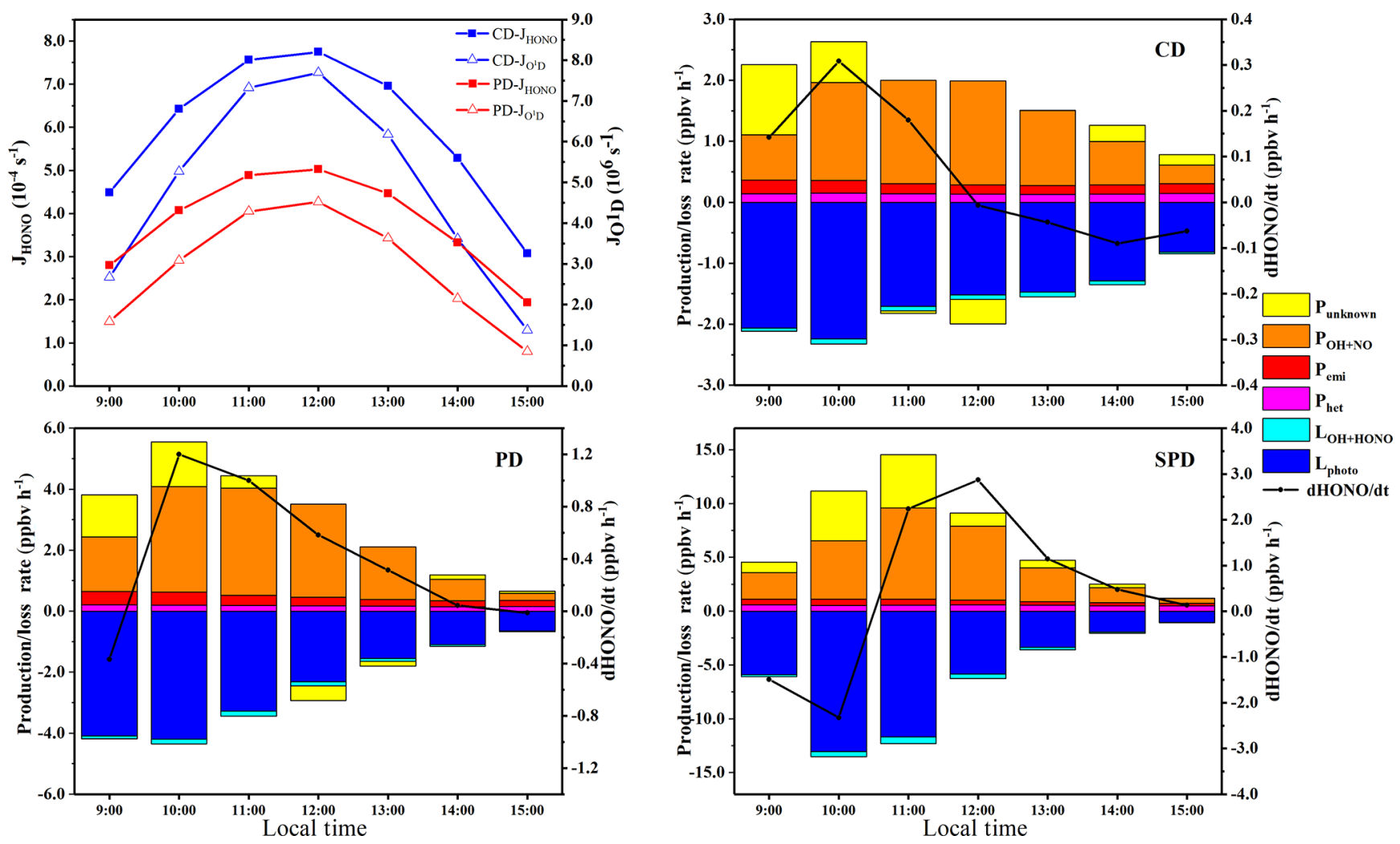

Figure 9. The average profiles of $J_{\mathrm{HONO}}$ and $J_{\mathrm{O}^{1} \mathrm{D}}$ concentrations during the daytime, and the production and loss rate of the daytime $\mathrm{HONO}$ in $\mathrm{CD}, \mathrm{PD}$, and SPD periods.

photolysis frequency and $\cdot \mathrm{OH}$ concentration could not be directly measured in this study. Therefore, the tropospheric ultraviolet and visible (TUV) transfer model of the National Center for Atmospheric Research (http://cprm.acom. ucar.edu/Models/TUV/Interactive_TUV/, last access: 2 October 2019; Hou et al., 2016) was used to calculate the

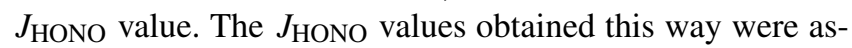
sumed for clear-sky days without clouds. $\mathrm{O}_{3}$ column density was measured by the Ozone Monitoring Instrument (OMI, https://ozonewatch.gsfc.nasa.gov/data/omi/Y2019/, last access: 30 August 2019). The $\mathrm{O}_{3}$ column density ranges from 292 to 306 DU during the entire period. Because the experimental site is situated in an urban region, the surface albedo is considered to be 0.13 (Sailor, 1995). The ground elevation and the measurement altitude are 168 and $188 \mathrm{~m}$ respectively. The concentration of $\mathrm{OH}$ radicals was calculated with the formulas of $\mathrm{NO}_{2}, \mathrm{O}_{3}$, and $J_{\mathrm{O}^{1} \mathrm{D}}$ in the Supplement (Rohrer and Berresheim, 2006). Aerosol effects were considered by using aerosol optical thickness (AOD), single scattering albedo (SSA), and the Ångström exponent as inputs in the TUV model. Typical AOD, SSA, and Ångström exponent values of $1.32,0.9$, and 1.3 , respectively, were adopted for the PD and SPD periods. In the CDs period, the respective values were 0.66, 0.89, and 1.07 (Che et al., 2015; Cui et al., 2018; Hou et al., 2016). We wanted to study the produc- tion and loss rate of HONO under the same output conditions from the TUV model in the PD and SPD periods; however, the impact of different pollution levels changed the daytime budget. Hence, the average profiles of $J_{\mathrm{HONO}}$ and $J_{\mathrm{O}^{1} \mathrm{D}}$ concentrations in the CD, PD, and SPD periods are shown in Fig. 9. The mean values of $J_{\mathrm{HONO}}$ and $\cdot \mathrm{OH}$ concentration at noon in the CD, PD, and SPD periods were $5.93 \times 10^{-4}$, $3.79 \times 10^{-4}$, and $3.79 \times 10^{-4}$ and $4.10 \times 10^{6}, 2.93 \times 10^{6}$, and $3.76 \times 10^{6}$ molec. $\mathrm{cm}^{-3}$, respectively. The results of the calculated $\mathrm{OH}$ radicals ranged $(0.58-11.49) \times 10^{6}$ molec. $\mathrm{cm}^{-3}$, and the mean value was $3.57 \times 10^{6}$ molec. $\mathrm{cm}^{-3}$ at noon in Zhengzhou.

Each production and loss rate of daytime HONO during $\mathrm{CD}, \mathrm{PD}$, and SPD periods is illustrated in Fig. $9 \mathrm{~m}$, together with $\mathrm{dHONO} / \mathrm{d} t$. $P_{\text {unknown }}$ was at a high level before midday. $P_{\text {unknown }}$ approached $0 \mathrm{ppbv} \mathrm{h}^{-1}$ after midday. In the CD, PD, and SPD periods, the mean values of $P_{\text {unknown }}$ were $0.26,0.40$, and $1.83 \mathrm{ppbv} \mathrm{h}^{-1}$, respectively; the mean values of $P_{\mathrm{OH}+\mathrm{NO}}$ were $1.14,2.07$, and $4.03 \mathrm{ppbv} \mathrm{h}^{-1}$, respectively; the mean values of $P_{\text {emi }}$ were $0.17,0.30$, and $0.43 \mathrm{ppbv} \mathrm{h}^{-1}$, respectively; and the mean values of $P_{\text {het }}$ were $0.14,0.18$, and $0.55 \mathrm{ppbvh}^{-1}$, respectively. The midday time $P_{\text {unknown }}$ $\left(1.83 \mathrm{ppbv} \mathrm{h}^{-1}\right)$ calculated in Zhengzhou during the winter haze pollution period was close to the result obtained from Beijing's urban area (Hou et al., 2016; $1.85 \mathrm{ppbv} \mathrm{h}^{-1}$ ). The 
$P_{\text {unknown }}$ contribution to daytime HONO sources in CD, PD, and SPD periods accounted for $15 \%, 14 \%$, and $28 \%$ of the HONO production rate $\left(P_{\text {unknown }}+P_{\mathrm{OH}+\mathrm{NO}}+P_{\text {emi }}+P_{\text {het }}\right)$, respectively. Previous studies (Spataro et al., 2013; Yang et al., 2014) showed that meteorological conditions, such as solar radiation and WS, can affect unknown sources. The low $P_{\text {unknown }}$ contribution of daytime HONO concentration may be related to the low solar radiation and low wind speed during severe pollution. The concentration of NO has a great influence on $P_{\mathrm{OH}+\mathrm{NO}}$, so the homogeneous reaction is still an important pathway of HONO production during the daytime. In addition to the photolysis of $\mathrm{HONO}$ and the homogeneous reaction of $\mathrm{HONO}$ and $\mathrm{OH}$, one, or more, important sink might exist to control the variation between the sources and sinks of the daytime HONO during complex contamination. However, further research is needed to analyze the unknown sources of daytime HONO.

\section{Conclusions}

Ambient HONO measurement, using AIM with other atmospheric pollutants and meteorological parameters, was conducted in the CPER. The HONO concentrations during the entire measurement varied from 0.2 to $14.8 \mathrm{ppbv}$, with an average of $2.5 \mathrm{ppbv}$. The HONO concentrations in the $\mathrm{CD}, \mathrm{PD}$, and SPD periods were $1.1,2.3$, and $3.7 \mathrm{ppbv}$, respectively, and the $\mathrm{HONO} / \mathrm{NO}_{2}$ ratios were $4.7 \%, 7.1 \%$, and $9.4 \%$, respectively. HONO concentration was a combined action of direct emissions and heterogeneous reaction, and the contributions of these two were higher than those of the homogeneous reactions in the first half of the night. However, the proportion of homogenization gradually increased in the second half of the night due to the steady increase in NO concentration. The hourly level of other HONO abatement pathways, aside from $\mathrm{OH}+\mathrm{HONO}$, should be at least $0.22 \mathrm{ppbv} \mathrm{h}^{-1}$ in the SPDs period. The sum of the frequency distributions of the $\mathrm{HONO}_{\text {emission }} / \mathrm{HONO}$ ratio (less than $20 \%$ ) was approximately $77 \%$, indicating that the direct emission of HONO was not the main source of the observed HONO level at night. The mean values of $\mathrm{HONO}_{\text {emission }} / \mathrm{HONO}$ in the $\mathrm{CD}, \mathrm{PD}$, and SPD periods were $17 \%, 16 \%$, and $16 \%$, respectively. This phenomenon means that the policy of restricting motor vehicles, published by the local government in January 2019, had a good effect on decreasing HONO emissions. In addition, when RH increased at the middle level, the heterogeneous HONO production increased, but it decreased when RH increased further due to the effect of surface water. The contribution of the three sources varied with different pollution levels. The mean values of $C_{\mathrm{HONO}}$ in the $\mathrm{CD}, \mathrm{PD}$, and SPD periods were $0.72 \times 10^{-2}, 0.64 \times 10^{-2}$, and $1.54 \times 10^{-2} \mathrm{~h}^{-1}$, respectively. In the SPDs period at nighttime, the heterogeneous conversion of $\mathrm{NO}_{2}$ appeared to be unimportant. Furthermore, the net production generated by homogeneous re- action may be the leading factor for the increase in HONO under high- $\mathrm{NO}_{x}$ conditions (i.e., the concentration of NO was relatively higher than that of $\mathrm{NO}_{2}$ ) at nighttime. The mean values of $P_{\mathrm{OH}+\mathrm{NO}}^{\text {net }}$ in the $\mathrm{CD}, \mathrm{PD}$, and $\mathrm{SPD}$ periods were $0.13,0.26$, and $0.56 \mathrm{ppbv} \mathrm{h}^{-1}$, respectively. Daytime HONO budget analysis showed that the mean values of $P_{\text {unknown }}$ in the CD, PD, and SPD periods were 0.26 , 0.40 , and $1.83 \mathrm{ppbv}^{-1}$, respectively. Although the values of $P_{\mathrm{OH}+\mathrm{NO}}$ had high uncertainty because of the variation of $\mathrm{NO}$ concentrations, $P_{\mathrm{OH}+\mathrm{NO}}$ contributed the most to HONO production during the daytime. After analysis, $C_{\mathrm{HONO}}, P_{\mathrm{OH}+\mathrm{NO}}^{\text {net }}$, and $P_{\text {unknown }}$ in the SPDs period were larger than those in the other periods, indicating that $\mathrm{HONO}$ participated in many reactions.

Data availability. All the data used in this paper are available from the corresponding author upon request (jiangn@zzu.edu.cn).

Supplement. The supplement related to this article is available online at: https://doi.org/10.5194/acp-20-7087-2020-supplement.

Author contributions. NJ, RZ, and, SL conceived and designed the study. QH analyzed the data and wrote the paper. LY performed aerosol sampling and data analyses.

Competing interests. The authors declare that they have no conflict of interest.

Financial support. This research has been supported by the $\mathrm{Na}-$ tional Natural Science Foundation of China (grant nos. 51808510 and 51778587), the National Key Research and Development Program of China (grant no. 2017YFC0212400), the Natural Science Foundation of the Henan Province of China (grant no. 162300410255), and the National Research Program for Key Issues in Air Pollution Control (grant no. DQGG0107).

Review statement. This paper was edited by Eliza Harris and reviewed by three anonymous referees.

\section{References}

Acker, K., Möller, D., Auel, R., Wieprecht, W., and Kalaß, D.: Concentrations of nitrous acid, nitric acid, nitrite and nitrate in the gas and aerosol phase at a site in the emission zone during ESCOMPTE 2001 experiment, Atmos. Res., 74, 507-524, https://doi.org/10.1016/j.atmosres.2004.04.009, 2005.

Alicke, B., Platt, U., and Stutz, J.: Impact of nitrous acid photolysis on the total hydroxyl radical budget during the Limitation of Oxidant Production/Pianura Padana Produzione di 
Ozono study in Milan, J. Geophys. Res., 107, 8196-8208, https://doi.org/10.1029/2000jd000075, 2002.

Alicke, B., Geyer, A., Hofzumahaus, A., and Holland, F.: $\mathrm{OH}$ formation by HONO photolysis during the BERLIOZ experiment, J. Geophys. Res., 108, 8247-8264, https://doi.org/10.1029/2001jd000579, 2003.

Ammann, M., Kalberer, M., Jost, D. T., Tobler, L., Rössler, E., Piguet, D., Gäggeler, H. W., and Baltensperger, U.: Heterogeneous production of nitrous acid on soot in polluted air masses, Nature, 395, 157-160, https://doi.org/10.1038/25965, 1998.

An, J., Li, Y., Chen, Y., Li, J., Qu, Y., and Tang, Y.: Enhancements of major aerosol components due to additional HONO sources in the North China Plain and implications for visibility and haze, Adv. Atoms. Sci., 30, 57-66, https://doi.org/10.1007/s00376012-2016-9, 2012.

Atkinson, R., Baulch, D. L., Cox, R. A., Crowley, J. N., Hampson, R. F., Hynes, R. G., Jenkin, M. E., Rossi, M. J., and Troe, J.: Evaluated kinetic and photochemical data for atmospheric chemistry: Volume $\mathrm{I}-$ gas phase reactions of $\mathrm{O}_{x}, \mathrm{HO}_{x}$, $\mathrm{NO}_{x}$ and $\mathrm{SO}_{x}$ species, Atmos. Chem. Phys., 4, 1461-1738, https://doi.org/10.5194/acp-4-1461-2004, 2004.

Che, H., Xia, X., Zhu, J., Wang, H., Wang, Y., Sun, J., Zhang, X., and Shi, G.: Aerosol optical properties under the condition of heavy haze over an urban site of Beijing, China, Environ. Sci. Pollut. Res., 22, 1043-1053, https://doi.org/10.1007/s11356014-3415-5, 2015.

Cui, L., Li, R., Zhang, Y., Meng, Y., Fu, H., and Chen, J.: An observational study of nitrous acid (HONO) in Shanghai, China: The aerosol impact on HONO formation during the haze episodes, Sci. Total Environ., 630, 1057-1070, https://doi.org/10.1016/j.scitotenv.2018.02.063, 2018.

Czader, B. H., Rappenglück, B., Percell, P., Byun, D. W., Ngan, F., and Kim, S.: Modeling nitrous acid and its impact on ozone and hydroxyl radical during the Texas Air Quality Study 2006, Atmos. Chem. Phys., 12, 6939-6951, https://doi.org/10.5194/acp12-6939-2012, 2012.

Dong, Z., Jiang, N., Duan, S., Zhang, L., Li, S., and Zhang, R.: Size distributions and size-segregated chemical profiles of particulate matter in a traffic tunnel of East-Central China, Atmos. Pollut. Res., 10, 1873-1883, https://doi.org/10.1016/j.apr.2019.08.001, 2019

Duan, J., Qin, M., Ouyang, B., Fang, W., Li, X., Lu, K., Tang, K., Liang, S., Meng, F., Hu, Z., Xie, P., Liu, W., and Häsler, R.: Development of an incoherent broadband cavityenhanced absorption spectrometer for in situ measurements of $\mathrm{HONO}$ and $\mathrm{NO}_{2}$, Atmos. Meas. Tech., 11, 4531-4543, https://doi.org/10.5194/amt-11-4531-2018, 2018.

Elshorbany, Y. F., Steil, B., Brühl, C., and Lelieveld, J.: Impact of HONO on global atmospheric chemistry calculated with an empirical parameterization in the EMAC model, Atmos. Chem. Phys., 12, 9977-10000, https://doi.org/10.5194/acp-129977-2012, 2012.

Elshorbany, Y. F., Crutzen, P. J., Steil, B., Pozzer, A., Tost, H., and Lelieveld, J.: Global and regional impacts of HONO on the chemical composition of clouds and aerosols, Atmos. Chem. Phys., 14, 1167-1184, https://doi.org/10.5194/acp-141167-2014, 2014.

Finlayson-Pitts, B. J., Wingen, L. M., Sumner, A. L., Syomin, D., and Ramazan, K. A.: The heterogeneous hydrolysis of $\mathrm{NO}_{2}$ in laboratory systems and in outdoor and indoor atmospheres: An integrated mechanism, Phys. Chem. Chem. Phys., 5, 223-242, https://doi.org/10.1039/b208564j, 2003.

Grassian, V. H.: Heterogeneous uptake and reaction of nitrogen oxides and volatile organic compounds on the surface of atmospheric particles including oxides, carbonates, soot and mineral dust: Implications for the chemical balance of the troposphere, Int. Rev. Phys. Chem., 20, 467-548, https://doi.org/10.1080/01442350110051968, 2001.

Hao, N., Zhou, B., Chen, D., and Chen, L.: Observations of nitrous acid and its relative humidity dependence in Shanghai, J. Environ. Sci.-China, 18, 910-915, https://doi.org/10.1016/s10010742(06)60013-2, 2006.

Harrison, R. M. and Collins, G. M.: Measurements of Reaction Coefficients of $\mathrm{NO}_{2}$ and $\mathrm{HONO}$ on Aerosol Particles, J. Atmos. Chem., 30, 397-406, https://doi.org/10.1023/A:1006094304069, 1998.

Harrison, R. M., Peak, J. D., and Collins, G. M.: Tropospheric cycle of nitrous acid, J. Geophys. Res., 101, 14429-14439, https://doi.org/10.1029/96jd00341, 1996.

Heland, J., Kleffmann, J., Kurtenbach, R., and Wiesen, P.: A new instrument to measure gaseous nitrous acid (HONO) in the atmosphere, Environ. Sci. Technol., 35, 3207-3212, https://doi.org/10.1021/es000303t, 2001.

Hendrick, F., Müller, J.-F., Clémer, K., Wang, P., De Mazière, M., Fayt, C., Gielen, C., Hermans, C., Ma, J. Z., Pinardi, G., Stavrakou, T., Vlemmix, T., and Van Roozendael, M.: Four years of ground-based MAX-DOAS observations of HONO and $\mathrm{NO}_{2}$ in the Beijing area, Atmos. Chem. Phys., 14, 765-781, https://doi.org/10.5194/acp-14-765-2014, 2014.

Hirokawa, J., Kato, T., and Mafuné, F.: In Situ Measurements of Atmospheric Nitrous Acid by Chemical Ionization Mass Spectrometry Using Chloride Ion Transfer Reactions, Anal. Chem., 81, 8380-8386, https://doi.org/10.1021/ac901117b, 2009.

Hou, S., Tong, S., Ge, M., and An, J.: Comparison of atmospheric nitrous acid during severe haze and clean periods in Beijing, China, Atmos. Environ., 124, 199-206, https://doi.org/10.1016/j.atmosenv.2015.06.023, 2016

Huang, R.-J., Yang, L., Cao, J., Wang, Q., Tie, X., Ho, K.-F., Shen, Z., Zhang, R., Li, G., Zhu, C., Zhang, N., Dai, W., Zhou, J., Liu, S., Chen, Y., Chen, J., and O'Dowd, C. D.: Concentration and sources of atmospheric nitrous acid (HONO) at an urban site in Western China, Sci. Total Environ., 593-594, 165-172, https://doi.org/10.1016/j.scitotenv.2017.02.166, 2017.

Jiang, N., Guo, Y., Wang, Q., Kang, P., Zhang, R., and Tang, X.: Chemical composition characteristics of $\mathrm{PM}_{2.5}$ in three cities in Henan, Central China, Aerosol Air Qual. Res., 17, 2367-2380, https://doi.org/10.4209/aaqr.2016.10.0463, 2017.

Jiang, N., Dong, Z., Xu, Y., Yu, F., Yin, S., Zhang, R., and Tang, X.: Characterization of $\mathrm{PM}_{10}$ and $\mathrm{PM}_{2.5}$ Source Profiles of Fugitive Dust in Zhengzhou, China, Aerosol Air Qual. Res., 18, 314-329, https://doi.org/10.4209/aaqr.2017.04.0132, 2018a.

Jiang, N., Duan, S., Yu, X., Zhang, R., and Wang, K.: Comparative major components and health risks of toxic elements and polycyclic aromatic hydrocarbons of $\mathrm{PM}_{2.5}$ in winter and summer in Zhengzhou: Based on three-year data, Atmos. Res., 213, 173184, https://doi.org/10.1016/j.atmosres.2018.06.008, 2018b.

Jiang, N., Li, Q., Su, F., Wang, Q., Yu, X., Kang, P., Zhang, R., and Tang, X.: Chemical characteristics and source appor- 
tionment of $\mathrm{PM}_{2.5}$ between heavily polluted days and other days in Zhengzhou, China, J. Environ. Sci.-China, 66, 188-198, https://doi.org/10.1016/j.jes.2017.05.006, 2018c.

Jiang, N., Wang, K., Yu, X., Su, F., Yin, S., Li, Q., and Zhang, R.: Chemical characteristics and source apportionment by two receptor models of size-segregated aerosols in an emerging megacity in China, Aerosol Air Qual. Res., 18, 1375-1390, https://doi.org/10.4209/aaqr.2017.10.0413, 2018d.

Jiang, N., Yin, S., Guo, Y., Li, J., Kang, P., Zhang, R., and Tang, $\mathrm{X}$.: Characteristics of mass concentration, chemical composition, source apportionment of $\mathrm{PM}_{2.5}$ and $\mathrm{PM}_{10}$ and health risk assessment in the emerging megacity in China, Atmos. Pollut. Res., 9, 2367-2380, https://doi.org/10.1016/j.apr.2017.07.005, 2018e.

Jiang, N., Li, L., Wang, S., Li, Q., Dong, Z., Duan, S., Zhang, R., and Li, S.: Variation tendency of pollution characterization, sources, and health risks of $\mathrm{PM}_{2.5}$-bound polycyclic aromatic hydrocarbons in an emerging megacity in China: Based on three-year data, Atmos. Res., 217, 81-92, https://doi.org/10.1016/j.atmosres.2018.10.023, 2019a.

Jiang, N., Liu, X., Wang, S., Yu, X., Yin, S., Duan, S., Shenbo, W., Zhang, R., and Li, S.: Pollution characterization, source identification, and health risks of atmospheric-particle-bound heavy metals in $\mathrm{PM}_{10}$ and $\mathrm{PM}_{2.5}$ at multiple sites in an emerging megacity in the Central Region of China, Aerosol Air Qual. Res., 19, 247-271, https://doi.org/10.4209/aaqr.2018.07.0275, 2019b.

Kim, D.-R., Lee, J.-B., Keun Song, C., Kim, S.-Y., Ma, Y.-1., Lee, K.-M., Cha, J.-S., and Lee, S.-D.: Temporal and spatial distribution of tropospheric $\mathrm{NO}_{2}$ over Northeast Asia using OMI data during the years 2005-2010, Atmos. Pollut. Res., 6, 768-776, https://doi.org/10.5094/apr.2015.085, 2015.

Kleffmann, J., Becker, K. H., Lackhoff, M., and Wiesen, P.: Heterogeneous conversion of $\mathrm{NO}_{2}$ on carbonaceous surfaces, Phys. Chem. Chem. Phys., 1, 5443-5450, https://doi.org/10.1039/a905545b, 1999.

Kurtenbach, R., Becker, K. H., Gomes, J. A. G., Kleffmann, J., Lorzer, J. C., Spittler, M., Wiesen, P., Ackermann, R., Geyer, A., and Platt, U.: Investigations of emissions and heterogeneous formation of HONO in a road traffic tunnel, Atmos. Environ., 35, 3385-3394, https://doi.org/10.1016/s1352-2310(01)00138$8,2001$.

Lelieveld, J., Gromov, S., Pozzer, A., and Taraborrelli, D.: Global tropospheric hydroxyl distribution, budget and reactivity, Atmos. Chem. Phys., 16, 12477-12493, https://doi.org/10.5194/acp-1612477-2016, 2016.

Li, Q., Jiang, N., Yu, X., Dong, Z., Duan, S., Zhang, L., and Zhang, R.: Sources and spatial distribution of $\mathrm{PM}_{2.5}$-bound polycyclic aromatic hydrocarbons in Zhengzhou in 2016, Atmos. Res., 216, 65-75, https://doi.org/10.1016/j.atmosres.2018.09.011, 2019.

Li, X., Brauers, T., Häseler, R., Bohn, B., Fuchs, H., Hofzumahaus, A., Holland, F., Lou, S., Lu, K. D., Rohrer, F., Hu, M., Zeng, L. M., Zhang, Y. H., Garland, R. M., Su, H., Nowak, A., Wiedensohler, A., Takegawa, N., Shao, M., and Wahner, A.: Exploring the atmospheric chemistry of nitrous acid (HONO) at a rural site in Southern China, Atmos. Chem. Phys., 12, 1497-1513, https://doi.org/10.5194/acp-12-1497-2012, 2012.

Liu, F., Beirle, S., Zhang, Q., van der A, R. J., Zheng, B., Tong, D., and $\mathrm{He}, \mathrm{K} .: \mathrm{NO}_{x}$ emission trends over Chinese cities estimated from OMI observations during 2005 to 2015, Atmos.
Chem. Phys., 17, 9261-9275, https://doi.org/10.5194/acp-179261-2017, 2017.

Liu, X., Jiang, N., Yu, X., Zhang, R., Li, S., Li, Q., and Kang, P.: Chemical characteristics, sources apportionment, and risk assessment of $\mathrm{PM}_{2.5}$ in different functional areas of an emerging megacity in China, Aerosol Air Qual. Res., 19, 2222-2238, https://doi.org/10.4209/aaqr.2019.02.0076, 2019.

Liu, Z., Wang, Y., Costabile, F., Amoroso, A., Zhao, C., Huey, L. G., Stickel, R., Liao, J., and Zhu, T.: Evidence of aerosols as a media for rapid daytime HONO production over China, Environ. Sci. Technol., 48, 14386-14391, https://doi.org/10.1021/es504163z, 2014.

Lu, X., Wang, Y., Li, J., Shen, L., and Fung, J. C. H.: Evidence of heterogeneous HONO formation from aerosols and the regional photochemical impact of this HONO source, Environ. Res. Lett., 13, 114002, https://doi.org/10.1088/1748-9326/aae492, 2018.

Markovic, M. Z., VandenBoer, T. C., and Murphy, J. G.: Characterization and optimization of an online system for the simultaneous measurement of atmospheric water-soluble constituents in the gas and particle phases, J. Environ. Monit., 14, 1872-1884, https://doi.org/10.1039/c2em00004k, 2012.

Michoud, V., Colomb, A., Borbon, A., Miet, K., Beekmann, M., Camredon, M., Aumont, B., Perrier, S., Zapf, P., Siour, G., AitHelal, W., Afif, C., Kukui, A., Furger, M., Dupont, J. C., Haeffelin, M., and Doussin, J. F.: Study of the unknown HONO daytime source at a European suburban site during the MEGAPOLI summer and winter field campaigns, Atmos. Chem. Phys., 14, 2805-2822, https://doi.org/10.5194/acp-14-2805-2014, 2014.

Pinto, J. P., Dibb, J., Lee, B. H., Rappenglück, B., Wood, E. C., Levy, M., Zhang, R. Y., Lefer, B., Ren, X. R., Stutz, J., Tsai, C., Ackermann, L., Golovko, J., Herndon, S. C., Oakes, M., Meng, Q. Y., Munger, J. W., Zahniser, M., and Zheng, J.: Intercomparison of field measurements of nitrous acid (HONO) during the SHARP campaign, J. Geophys. Res.-Atmos., 119, 5583-5601, https://doi.org/10.1002/2013jd020287, 2014.

Qin, M., Xie, P., Su, H., Gu, J., Peng, F., Li, S., Zeng, L., Liu, J., Liu, W., and Zhang, Y.: An observational study of the $\mathrm{HONO}-\mathrm{NO}_{2}$ coupling at an urban site in Guangzhou City, South China, Atmos. Environ., 43, 5731-5742, https://doi.org/10.1016/j.atmosenv.2009.08.017, 2009.

Rappenglück, B., Lubertino, G., Alvarez, S., Golovko, J., Czader, B., and Ackermann, L.: Radical precursors and related species from traffic as observed and modeled at an urban highway junction, J. Air Waste Manage. Assoc., 63, 1270-1286, https://doi.org/10.1080/10962247.2013.822438, 2013.

Roberts, J. M., Veres, P., Warneke, C., Neuman, J. A., Washenfelder, R. A., Brown, S. S., Baasandorj, M., Burkholder, J. B., Burling, I. R., Johnson, T. J., Yokelson, R. J., and de Gouw, J.: Measurement of HONO, HNCO, and other inorganic acids by negative-ion proton-transfer chemical-ionization mass spectrometry (NI-PT-CIMS): application to biomass burning emissions, Atmos. Meas. Tech., 3, 981-990, https://doi.org/10.5194/amt-3981-2010, 2010

Rohrer, F. and Berresheim, H.: Strong correlation between levels of tropospheric hydroxyl radicals and solar ultraviolet radiation, Nature, 442, 184-187, https://doi.org/10.1038/nature04924, 2006. 
Sailor, D. J.: Simulated Urban Climate Response to Modifications in Surface Albedo and Vegetative Cover, J. Appl. Meteorol., 34, 1694-1704, https://doi.org/10.1175/1520-0450-34.7.1694, 1995.

Sander, S., Friedl, R., Golden, D., Kurylo, M., Huie, R., Orkin, V., Moortgat, G., Ravishankara, A. R., Kolb, C., Molina, M., and Finlayson-Pitts, B.: Chemical Kinetics and Photochemical Data for Use in Atmospheric Studies; JPL Publication 02-25, available at: http://jpldataeval.jpl.nasa.gov/ (last access: 5 April 2019), 2003.

Shen, L. J. and Zhang, Z. F.: Heterogeneous reactions of $\mathrm{NO}_{2}$ on the surface of black carbon, Prog. Chem., 25, 28-35, 2013.

Sörgel, M., Regelin, E., Bozem, H., Diesch, J.-M., Drewnick, F., Fischer, H., Harder, H., Held, A., Hosaynali-Beygi, Z., Martinez, M., and Zetzsch, C.: Quantification of the unknown HONO daytime source and its relation to $\mathrm{NO}_{2}$, Atmos. Chem. Phys., 11, 10433-10447, https://doi.org/10.5194/acp-11-104332011, 2011.

Spataro, F., Ianniello, A., Esposito, G., Allegrini, I., Zhu, T., and $\mathrm{Hu}$, M.: Occurrence of atmospheric nitrous acid in the urban area of Beijing (China), Sci. Total Environ., 447, 210-224, https://doi.org/10.1016/j.scitotenv.2012.12.065, 2013.

Stutz, J., Alicke, B., Ackermann, R., Geyer, A., Wang, S., White, A. B., Williams, E. J., Spicer, C. W., and Fast, J. D.: Relative humidity dependence of HONO chemistry in urban areas, J. Geophys. Res., 109, 3307-3319, https://doi.org/10.1029/2003jd004135, 2004.

Su, H., Cheng, Y. F., Cheng, P., Zhang, Y. H., Dong, S., Zeng, L. M., Wang, X., Slanina, J., Shao, M., and Wiedensohler, A.: Observation of nighttime nitrous acid (HONO) formation at a nonurban site during PRIDE-PRD2004 in China, Atmos. Environ., 42, 6219-6232, https://doi.org/10.1016/j.atmosenv.2008.04.006, 2008a.

Su, H., Cheng, Y. F., Shao, M., Gao, D. F., Yu, Z. Y., Zeng, L. M., Slanina, J., Zhang, Y. H., and Wiedensohler, A.: Nitrous acid (HONO) and its daytime sources at a rural site during the 2004 PRIDE-PRD experiment in China, J. Geophys. Res., 113, D14312, https://doi.org/10.1029/2007jd009060, 2008b.

Tan, Z., Rohrer, F., Lu, K., Ma, X., Bohn, B., Broch, S., Dong, H., Fuchs, H., Gkatzelis, G. I., Hofzumahaus, A., Holland, F., Li, X., Liu, Y., Liu, Y., Novelli, A., Shao, M., Wang, H., Wu, Y., Zeng, L., Hu, M., Kiendler-Scharr, A., Wahner, A., and Zhang, Y.: Wintertime photochemistry in Beijing: observations of $\mathrm{RO}_{x}$ radical concentrations in the North China Plain during the BEST-ONE campaign, Atmos. Chem. Phys., 18, 1239112411, https://doi.org/10.5194/acp-18-12391-2018, 2018.

Tong, S., Hou, S., Zhang, Y., Chu, B., Liu, Y., He, H., Zhao, P., and Ge, M.: Comparisons of measured nitrous acid (HONO) concentrations in a pollution period at urban and suburban Beijing, in autumn of 2014, Sci. China Chem., 58, 1393-1402, https://doi.org/10.1007/s11426-015-5454-2, 2015.

Tong, S., Hou, S., Zhang, Y., Chu, B., Liu, Y., He, H., Zhao, P., and Ge, M.: Exploring the nitrous acid (HONO) formation mechanism in winter Beijing: direct emissions and heterogeneous production in urban and suburban areas, Faraday Discuss., 189, 213230, https://doi.org/10.1039/c5fd00163c, 2016.

VandenBoer, T. C., Markovic, M. Z., Sanders, J. E., Ren, X., Pusede, S. E., Browne, E. C., Cohen, R. C., Zhang, L., Thomas, J., Brune, W. H., and Murphy, J. G.: Evidence for a nitrous acid (HONO) reservoir at the ground surface in Bakersfield, CA, dur- ing CalNex 2010, J. Geophys. Res.-Atmos., 119, 9093-9106, https://doi.org/10.1002/2013jd020971, 2014.

Vogel, B., Vogel, H., Kleffmann, J., and Kurtenbach, R.: Measured and simulated vertical profiles of nitrous acid - Part II. Model simulations and indications for a photolytic source, Atmos. Environ., 37, 2957-2966, https://doi.org/10.1016/s13522310(03)00243-7, 2003.

Wang, S., Zhou, R., Zhao, H., Wang, Z., Chen, L., and Zhou, B.: Long-term observation of atmospheric nitrous acid (HONO) and its implication to local $\mathrm{NO}_{2}$ levels in Shanghai, China, Atmos. Environ., 77, 718-724, https://doi.org/10.1016/j.atmosenv.2013.05.071, 2013.

Wang, S., Yin, S., Zhang, R., Yang, L., Zhao, Q., Zhang, L., Yan, Q., Jiang, N., and Tang, X.: Insight into the formation of secondary inorganic aerosol based on high-timeresolution data during haze episodes and snowfall periods in Zhengzhou, China, Sci. Total Environ., 660, 47-56, https://doi.org/10.1016/j.scitotenv.2018.12.465, 2019.

Winer, A. M. and Biermann, H. W.: Long pathlength differential optical absorption spectroscopy (DOAS) measurements of gaseous $\mathrm{HONO}, \mathrm{NO}_{2}$ and $\mathrm{HCNO}$ in the California South Coast Air Basin, Res. Chem. Intermed., 20, 423-445, https://doi.org/10.1163/156856794X00405, 1994.

Wojtal, P., Halla, J. D., and McLaren, R.: Pseudo steady states of HONO measured in the nocturnal marine boundary layer: a conceptual model for HONO formation on aqueous surfaces, Atmos. Chem. Phys., 11, 3243-3261, https://doi.org/10.5194/acp11-3243-2011, 2011.

Xu, Z., Wang, T., Wu, J., Xue, L., Chan, J., Zha, Q., Zhou, S., Louie, P. K. K., and Luk, C. W. Y.: Nitrous acid (HONO) in a polluted subtropical atmosphere: Seasonal variability, direct vehicle emissions and heterogeneous production at ground surface, Atmos. Environ., 106, 100-109, https://doi.org/10.1016/j.atmosenv.2015.01.061, 2015.

Yang, L., Wang, S., Duan, S., Yan, Q., Jiang, N., Zhang, R., and Li, S.: Characteristics and formation mechanisms of secondary inorganic ions in $\mathrm{PM}_{2.5}$ during winter in a central city of China: Based on a high time resolution data, Atmos. Res., 233, 104696, https://doi.org/10.1016/j.atmosres.2019.104696, 2020.

Yang, Q., Su, H., Li, X., Cheng, Y., Lu, K., Cheng, P., Gu, J., Guo, S., Hu, M., Zeng, L., Zhu, T., and Zhang, Y.: Daytime HONO formation in the suburban area of the megacity Beijing, China, Sci. China Chem., 57, 1032-1042, https://doi.org/10.1007/s11426013-5044-0, 2014.

Zhang, B. and Tao, F.-M.: Direct homogeneous nucleation of $\mathrm{NO}_{2}, \mathrm{H}_{2} \mathrm{O}$, and $\mathrm{NH}_{3}$ for the production of ammonium nitrate particles and HONO gas, Chem. Phys. Lett., 489, 143-147, https://doi.org/10.1016/j.cplett.2010.02.059, 2010.

Zhang, W., Tong, S., Ge, M., An, J., Shi, Z., Hou, S., Xia, K., Qu, Y., Zhang, H., Chu, B., Sun, Y., and He, H.: Variations and sources of nitrous acid (HONO) during a severe pollution episode in Beijing in winter 2016, Sci. Total Environ., 648, 253262, https://doi.org/10.1016/j.scitotenv.2018.08.133, 2019. 